\title{
Śmiech po ojczyźnie. Patologia społeczeństwa początków epoki rozbiorowej
}

Marek Nalepa 
MAPTS Seria IV 1998

\section{Marek Nalepa}

\section{Śmiech po ojczyźnie. Patologia społeczeństwa początków epoki rozbiorowej}

\section{Zabawy na grobie Ojczyzny}

I. Na chorobowy stan psychiki narodu polskiego po ostatnim rozbiorze zwracano uwagę wielokrotnie. Ludwik Dębicki w swej czterotomowej monografii poświęconej życiu towarzyskiemu, politycznemu i literackiemu w Puławach w drugiej połowie XVIII i na początku XIX wieku dał taki oto obraz ówczesnego społeczeństwa:

Po pogromie maciejowickim, zdobyciu Warszawy, rzezi na Pradze, wywiezieniu króla do Grodna i ostatnim rozbiorze - rozpacz ogarniała jednostki, były liczne wypadki samobójstw, wielu postradało zmysły, inni wpadali w dziwactwa, szukali zapomnienia w ekscentrycznościach, inni w wirze światowych zabaw, ale i ci, którzy szaleli w chwili ostatecznego kataklizmu wśród wesołości, zbytku i uciech, jak i ci co w czarną zapadali melancholię, wynieśli z tej ostatniej katastrofy piętno chorobliwego, nieprawidłowego stanu, jakie i następnym miało się udzielać pokoleniom (...) Nie była to śmierć społeczeństwa zgrzybiałego, przeżytego, które umiera na uwiąd czy marazm, na bezkrwistość - przeciwnie - grom strzaskał rosłego przez wieki dęba, kiedy nowe wiosna poruszyła jego soki, okryła świeżym liściem jego nadpróchniałe konary (...) Organizm całego społeczeństwa wyczerpany długą, konwulsyjną agonią, wpa- 
da w stan obumarcia, a przez prawo reakcji doznaje niemal ulgi. Szał zabaw, tańców, zbytków na świeżych mogiłach był także chorobliwą gorączką ${ }^{1}$.

Zgodzić się wypada z opinią Marii Janion o istnieniu ścisłej zależności między chorobą a historią, między stanem ojczyzny a stanem zdrowia jej obywateli ${ }^{2}$. Bo oto nawet w środowiskach zdrajców Konstytucji Majowej po trzecim rozbiorze nasila się patriotyczna patologia. Dyzma Bończa Tomaszewski zmienia nazwisko i ubiór, aby nie dać się nikomu rozpoznać. Obłąkany Rudnicki, zausznik Szczęsnego Potockiego, udaje wisielca. Wyśmiewany przez Niemcewicza Suchorzewski do zmęczenia powtarza dzieje 3 maja i swoją rozpacz. Ze smutkiem i przygnębieniem obnosi się Bistecki. Winiarski, który jako komendant wpuścił do Krakowa Prusaków, pocztywany powszechnie za zdrajcę, błąka się po Galicji, gdzie wszędzie zamykane są przed nim drzwi ${ }^{3}$.

Granice zasięgu patologii, dewiacji i dziwactw są po 1795 roku znacznie szersze niż po pierwszym rozbiorze, kiedy to zaobserwowano zaledwie kilka reakcji tego typu. Józef Frank, pisząc sprawozdanie o chorobach, jakie nękały mieszkańców Wilna na początku ubiegłego stulecia, zwraca uwagę na nasilenie się przypadków „melancholii” i „manii” o religijno-patriotycznym podłożu ${ }^{4}$.

Dawniej przed laty — pisze Eustachy Iwanowski - pomięszanie, wariacja, ten stan dla patrzących tak bolesny, a dla cierpiących niewymownie okropny, straszniejszy od śmierci, w naszym życiu narodowym, rycerskim, szlacheckim, jako i ludowym, rzadko się wydarzał, chyba jako szczególny organiczny wypadek, albo też skutek rozuzdanej jakiejś namiętności. W tych czasach ten upadek nie ducha, ale organizmu, stał się wielu ludzi udziałem; na wygnaniach syberyjskich, na tułaczce zachodniej niemałą liczbę takich ofiar widzimy ${ }^{5}$.

Szaleństwo czasami przybierało znamiona grupowego. Pamiętnikarze ówcześni, powołując się na autopsję bądź relacje naocznych świadków, opisują otwarcie grobu posła z Upity, Władysława Sicińskiego, który niechlubnie zasłynął jako pierwszy poseł zrywający sejm. W środku znaleziono doskonale zmumifikowane zwłoki. Wydobyto je na zewnątrz i przez kilka lat włóczono po cmentarzach, poniewierano po drogach, żydowskich karczmach, piętnowano nimi zdrajców, rzucano jako „przeklęctwo” na progi domów. Ulitowano się nad nimi dopiero w drugim dziesiątku XIX wieku, chowając je w kącie kaplicy nowego upickiego kościoła ${ }^{6}$.

${ }^{1}$ L. Dębicki, Pulawy (1762-1830). Monografia z życia towarzyskiego, politycznego i literackiego, Lwów 1887, t. 2, s. 3-4.

2 M. Janion, Wobec zła, Chotomów 1989, s. 12.

${ }^{3}$ Zob. Pamiętniki Wincentego Placzkowskiego — ponucznika dawnej gwardii cesarsko-francuskiej, Żytomierz 1861, s. 18.

${ }^{4}$ Cyt. za: A. Kowalczykowa, Rornantyczni szaleńcy, Warszawa 1977, s. 11.

5 (E. Iwanowski) Helleniusz, Wspommienia narodowe, Paryż 1861, s. 366.

- Shańbiono także zwłoki Szczęsnego Potockiego. Przed uroczystościami pogrzebowymi nieznani rabusie wdarli się do kaplicy przycmentarnej i z trupa zdarli bogaty mundur rosyjski z odznaczeniami. Truchło pana 
II. Po trzecim rozbiorze daje się zaobserwować charakterystyczne zjawisko, które przez wiele lat było przedmiotem etycznych rozważań przedstawicieli następnych pokoleń, stanowiąc podstawę dla sądu, że społeczeństwo polskie końca XVIII wieku nie przejęło się upadkiem państwa, a co gorsza w haniebny sposób oddawało się zabawom i hulankom na grobie Rzeczypospolitej. Z dzisiejszej perspektywy w tym „upokarzającym” szale i upojeniu widzieć należy swoistą reakcję obronną na pustkę wypełniającą umysły Polaków po psychicznym porażeniu i oszołomieniu faktami, które wraz z upływem czasu postrzegano coraz częściej jako nieodwracalne. Niewątpliwie więc rację ma Ludwik Dębicki stwierdzający, że był to przejaw chorobliwego odreagowania, który należy umieścić w rzędzie takich zachowań i stanów psychicznych po 1795 roku jak „czarna melancholia”, rozpacz, obłąkanie, próby samobójcze ${ }^{7}$. Organizm bowiem całego społeczeństwa, wyczerpany długą, konwulsyjną agonią popadł w stan obumarcia i w żywiole zabaw, tańców, redut, zbytków, orgii doznawał chwilowego ukojenia. Potwierdza tę opinię wielu ówczesnych pamiętnikarzy, np. A. J. Czartoryski, J. Krasiński, L. Dembowski, J. D. Ochocki, J. Drzewicki, zgodnie uznając, że ofiary pijaństwa, pojedynków, rozwiązłości były wówczas tak liczne, jak gdyby jaka zaraza przeszła przez Polskę i, rzecz najważniejsza, do tego hulaszczego pokolenia przynależeli ludzie, którzy później dosłużyli się wysokich rang wojskowych lub stali się wybitnymi mężami stanu. Brylował wśród nich sam ksiązę Józef Poniatowski, który w otrzymanym od Stanisława Augusta Pałacu pod Blachą wraz z panią Vauban pogrążał się przez kilka lat w wyszukanych uciechach i zabawach, gdy w tym samym czasie po pustych ulicach Warszawy krążyły pruskie patrole i coraz częściej rozlegała się obca mowa. Pod nieobecność księcia generała bawiono się także na zabój w patriotycznych Puławach, gdzie piło się do umoru, a tańczono do upadłego. Bale, spektakle, koncerty na dworze w Petersburgu do tego stopnia zaprzątały umysł Adama Jerzego Czartoryskiego, że, jak sam powiada, „zapomniał, w jakim kraju i wśród jakich ludzi się znajduje" 8 . Gorszą się atmosferą Grodna przebywający tam cudzoziemcy, zastanawiając się nad wymową dzikich bachanalii i szalonych uczt organizowanych przez Polaków w obliczu otwierającego się grobu i perspektywy niebytu państwowego. Francuz De Paulè swoje obserwacje zamyka następującym komentarzem:

W każdym razie Grodno w 1795 roku wcale nie było podobnym do miasta w stanie oblężenia, jak się spodziewano, że je tak postawi zaniepokojony z początku Repnin: owszem życie płynęło swobodnie i wesoło, zdawało się, iż Grodno jest stolicą króla świetnie panującego nad narodem pełnym politycznej żywotności i siły. A życie dworskie szło szalonym prądem wesołości i niezwykłego ruchu; piękne i zalotne kobiety, świetna młodzież, dały liczne powody do gorszących nawet stosunków, rozwinęły się amory i romanse 9 .

na Tulczynie porzucili pod ścianą kaplicy.

7 L. Dębicki, Putauy..., op. cit., t. 2, s. 3-4.

8 Zob. J. Skowronek, Adam Jerzy Czartoryski 1770-1761, Warszawa 1994, s. 45.

9 Cyt. za: P. Jaxa Bykowski, Dwór królew'ski w' Grodnie. Epizod biograficzny (1795-1797), Warszawa 1884, s. 73. 
Również Dymitr lłowajski nie umie pogodzić objawów smutku i rozpaczy manifestowanych na sesjach sejmu z 1793 roku z zabawami poza posiedzeniami, oraz ulic i przedmieść zapełnionych rosyjskimi „obozami, widetami i patrolami” z balami i obfitymi wieczerzami „ciągnącymi się długim, nieustającym szeregiem”. Jedynym wytłumaczeniem tych rażących kontrastów jest dla niego myśl, iż tutejsze społeczeństwo pragnie odurzyć się i zapomnieć o tym, że traci wszystko 10 .

Adam Jerzy Czartoryski w Żywocie Juliana Ursyna Niemcewicza stara się usprawiedliwić tego typu zachowania, podkreślając fakt, że były one wynikiem nagłej katastrofy intelektualno-emocjonalnej, obejmującej wszystkie niemal dziedziny życia, od polityki poczynając, a na religii kończąc. Usiłowano ją zatrzeć lub przeczekać, pogrążając się w zapomnieniu i w chorobliwej nieczułości. Ten sposób reagowania na upadek państwa był powszechny przede wszystkim pośród młodzieży, albowiem „starzy” wraz z końcem „Królestwa Polskiego” zamknęli się w czterech ścianach swych domów, unikając wszelkich kontaktów ze światem.

Z pewnością opinia autora Barda polskiego zasługuje na szczególniejszą uwagę, gdyż sam, po części z przymusu, po części z własnej woli, uczestniczył w różnego rodzaju zabawach organizowanych na dworach i w pałacach rosyjskich:

Rozstrojenie, które wówczas [po upadku Konstytucji Majowej - M. N.] spadło na duch narodowy, zwątpienie o sobie, o własnych usiłowaniach i przekonaniach, łatwe odchęcanie się, brak statku i stałości, w młodzieży zaś zatarcie przeszłości, bezwzgląd na przyszłość i rzucanie się w odurzające zabawy ku życiu bez celu, w kilku nadchodzących generacjach stały się dla Polski na długo jakby chorobą chroniczną, której symptomy czasem zmniejszają się, nikną, lecz której zaród nie jest jeszcze uleczony, i która przy odnawiających się, szkodzących wypadkach znowu się odzywa i znowu może grasować. Nie dziw, że z własnego normalnego toru raz zbite umysły zbłądziły, nie trafiły do celu wszystkim zarówno drogiego, i że podług chwili i następnych, nam zawsze przeciwnych zdarzeń, miotane były między różnymi ostatecznościami rozpaczy, to oddając się bezsilnemu zwątpieniu, to rzucając się na oślep w niepodobne zapędy. Wiara, bądź co bądź, w życie i przyszłość Polski, upadkiem wówczas doznanym, zbyt srogo nadwyrężona, nie mogła się długo w jej synach dość stale, dość skutecznie i powszechnie, z smutnych zwątpień wydźwignąć i odżywić ${ }^{11}$.

Z punktu widzenia współczesnej psychiatrii owa skłonność do szaleńczych zabaw żywo przypomina psychopatie o podłożu histerycznym, z takimi objawami jak: zafałszowanie dotyczące obrazu świata, zawodność mechanizmu samokontroli, burzliwość emocjonalna,

${ }^{10}$ D. Iłowajski, Grodnienskij Sejm 1793, Moskwa 1870, s. 147, 150, cyt. za: A. J. Rolle, Gawędy historyczne, t. 2, Kraków 1966, s. 326-327.

" A. J. Czartoryski, Żyvot J. U. Niemcewicza, Berlin-Poznań 1860, s. 84. 
dyspozycje psychiczne w kierunku teatralnych gestów i funkcjonowania na „ulgowych" papierach. W konwersji tej, zauważa Antoni Kępiński, dominujący jest infantylny stosunek do otaczającej rzeczywistości, wszystko dzieje się na niby, jest bardziej zabawą niż życiem na serio. Nawet śmierć przybiera tutaj formy teatralne i taneczne, traci swą powagę i majestat. Przyjmując jednakże w sytuacji zagrożenia postawę historyczną, człowiek czuje się bezpieczniejszy, gdyż nie przeżywa tak silnie odpowiedzialności za własne czyny i decyzje, przesuwając ciężar ten na otoczenie albo wyższą konieczność. Histeryk - co warto podkreślić — nie ma własnej hierarchii wartości, a zasadniczo ma je dwie, jedną „pod otoczenie”, drugą podświadomą, chaotyczną i pełną sprzeczności, co w pewnym stopniu ułatwia mu przystosowanie się do trudnej sytuacji ${ }^{12}$.

Szał zabaw i hedonizm należą do najbardziej charakterystycznych reakcji na śmierć i sytuacje zagrożenia, zwłaszcza w grupach czy zbiorowościach niezdolnych do ujęcia w wyższe sensy owych krańcowości. Boccaccio wspomina, że w czasach rozprzestrzeniania się czarnej śmierci w połowie XIV wieku część społeczeństwa w sposób maksymalny wykorzystywała możliwości życia, w przekonaniu, że najlepszym lekarstwem na zarazę jest zapomnieć o niej, pić do upadłego i mieć się wesoło, nie dostrzegając tego co się dzieje wokół. Inni znowu, również w sposób skrajny, usiłowali rezygnować z wartości życia, decydując się na posuniętą niemal do patologii ascezę.

W średniowieczu gorszono się zabawami i tańcami na cmentarzach, co nawet zostało potępione w 1435 r. przez sobór w Bazylei. Być może ten sposób „oswajania śmierci” wytworzył literackie i ikonograficzne motywy danse macabre. Znana jest spisana w norymberskiej kronice legendarna opowieść o tancerzach z Kolbigk, w której taniec i śmierć zostały sobie przeciwstawione w planie aksjologii. Msza wigilijna odprawiana w tamtejszym kościele została zakłócona przez grupę mężczyzn i kobiet, śpiewających i tańczących na pobliskim cmentarzu. Nie pomogły napomnienia kapłana, który zdesperowany poprosił w końcu niebiosa, by występni musieli tak tańczyć przez dwanaście lat. Po uplywie tego okresu zniesiona została z lekkomyślnych młodzieńców klątwa przez arcybiskupa Magdeburga. Troje spośród ponad dwudziestu tancerzy i tancerek natychmiast umarło.

Wspomniana hulaszcza dekadencja po drugim i trzecim rozbiorze Polski była jednak nie tylko formą zapomnienia i nieczułości na rzeczywistość polityczną końca XVIII wieku, ale także jednym ze sposobów pogodzenia się z faktem śmierci, obejmującej swoim zasięgiem zorganizowane życie zbiorowe. Było hedonistyczną formą wyżycia się w oczekiwaniu na skutki zagłady narodowej, negatywnym biegunem rozpaczy, tak samo jak ona wyrażą̨cym zachwianie wiary w przyszłość i niemożność wydźwignięcia się z psychicznej prostracji.

Jest jakiś heroizm straceńczy - pisze Mieczysław M. Smolarski — w tej zabawie, jest zarazem jeden z najprostszych objawów pychy ludzkiej i całych

12 A. Kępiński, Psychopatologia nenuic, Warszawa 1986, s. 25-45. 
narodów — tak tańczyła nad grobem matki i ojczyma, jednym tańcem szalonym uniesienia i bólu, Elektra ${ }^{13}$.

Korzystano z różnorakich form użycia i wyżycia się, od pijaństwa, burd i pojedynkowania się poczynając, poprzez hazard (faraon, basset, lansquenet, Grobhaus, cinque et neuf, quinze, lotte, tryszak, gra w kości), gry w bilard, szachy, wszelkiego rodzaju ciuciubabki, gotowanie, „lisy”, „płytki”, pantonimy sceniczne, quizy językowe, pikniki, manewry i parady wojskowe, popisy sztukmistrzów, linoskoczków, akrobatów, wędrownych trup aktorskich, zwykle włoskich lub francuskich, a kończąc na „tańcujących herbatach i kawach”, maskaradach z „reduty i przedstawień dramatycznych ułożonych", balach maskowych i półmaskowych, karnawałowych, migdałowych, tańcach publicznych. Bawiono się dosłownie wszędzie: na dworach i w pałacach, w dworkach, na jarmarkach, w kasynach, w karczmach, teatrach, cyrkach, na ulicach i placach.

Ta chorobliwa dążność do wyszumienia się i wyżycia po 1795 r. zataczała nad wyraz szerokie kręgi. Towarzyszyła jej nierzadko rozwięzłość moralna. Jan Duklan Ochocki wspomina kobiety, które „z wielkiego patriotyzmu pogrążyły się w łatwych romansach”, zmieniając kochanków niczym rękawiczki. Mężowie nie pozostawali im dłużni i nawzajem dopuszczali się niewierności, rujnując się dla kobiet, które im się chwilowo podobały.

Tu w Lwowie - pisze w swych pamiętnikach — chociaż napływ Polaków ze wszystkich stron był niezmierny, tak że do najciaśniejszego kątka całe zalał miasto, i zdawało się, że wszystkie prowincje słowo sobie dały tu się zgromadzić; chociaż zbiorowisko to składało się z osób najmajętniejszych, najlepiej wychowanych, najlepiej ukształconych i najwyżej stojących, nikt nawet o klęskach ogólnych, o kraju i o sytuacji jego nowej nie podniósł głosu, żadnej przyszłości, żadnego jutra przed nami, nic co by opłakiwać można, nic czego by się trwożyć potrzeba, nic co by dokonać należało. Bawiono się bez końca, kochano na zabój (...) grano w karty bez pamięci, upijano się śmiertelnie i szalono jak za dobrych czasów (...) Płochość tego tłumu była niepojęta, zepsucie nieopatrzne, niesłychane (...) Pojąć dziś nie mogę, jak tę publiczność na to wszystko wystarczało; były to nasze nieszczęśliwe zapusty, któreśmy później długim postem dyscyplinowani odpokutować musieli ${ }^{14}$.

Do rangi niemal symbolu urasta wydarzenie, jakie miało miejsce w najbardziej chyba rozbawionym w tym czasie Lwowie. Poruszyło ono mocno umysły wielu Polaków. Otóż

\footnotetext{
${ }^{13}$ M. M. Smolarski, Poeta „Wiersza do legiów” Cyprian Godebski, Kraków 1910, s. 9. W innym miejscu wymienionej pozycji autor określa granice społeczne tych zjawisk: „Bawią się ci, którzy mają — tym, co nie mają, rząd obcy stara się o kredyt łatwy. Starają się zapomnieć wśród szaleństw i orgii o nieszczęściu ojczyzny, śmieją się i tańczą wczorajsi wodze i jutrzejsi bohaterowie, wczoraj awanturnicy i karciarze, jutro żołnierze, tańczą, jakby ich gnębiła ta jedna straszna o nieszczęściu myśl, której nie mogą żadną miarą odegnać" (s. 8)

${ }_{14}$ Pamiętniki Jana Duklana Ochockiego, wyd. J. I. Kraszewski, Wilno 1857, t. 3, s. 73-74.
} 
w budynku przerobionego z kościoła św. Krzyża oo. Franciszkanów tamtejszego Teatru Starego, gdzie szalano na redutach i balach, jeden z aktorów Wojciecha Bogusławskiego odkrył pewnego razu pod sceną trumny ze szczątkami zwłok ludzkich. Jak się okazało, przebudowy kościoła na teatr dokonano pospiesznie i niedbale, wskutek czego nikt nie raczył sprawdzić zawartości wnętrza sklepienia, na którym niegdyś stał ołtarz, a później scena. Odkrycie to, jak wspomniano, wywołało ogromną sensację wśród mieszkańców stałych i przyjezdnych Lwowa, okazało się bowiem, że bawiono się hucznie i ochoczo na ludzkich mogiłach. Jakie były skutki tego poruszenia, niestety, nie wiemy ${ }^{15}$.

Zdarzały się także przypadki, i to stosunkowo częste, że pragnienia zabawy przykrywano płaszczykiem filantropii. Organizowano więc bale na rzecz ubogich, dając zwykle na tego rodzaju imprezach upust swym ukrywanym dotąd za zasłoną konwenansu i dobrych manier żądzom i namiętnościom. Zbierało się na takich balach do 1200 osób w wyszukanych maskach i odpowiednio dobranych kostiumach ${ }^{16}$. Nie omieszkał pokpiwać sobie $z$ tego typu akcji dobroczynnych twórca ostrych epigramów, w zabawnej fraszce:

Spieszył na bal ubogich jakiś panicz modny,

Zastąpił mu żebraczek i nagi, i głodny.

„Nie przykrz się — rzecze panicz — widzę, żeś w potrzebie, I dlatego też idę tańcować dla ciebie" ${ }^{17}$.

Gorszy się wesołością i zabawami mieszkańców Krakowa w chwilach konania Polski Stanisław Staszic.

Tu i ówdzie pojawiają się wypowiedzi ganiące postawy Polek, które niebaczne na śmierć polityczną Rzeczypospolitej, próbują w różnoraki sposób szukać kontaktów towarzyskich, a nawet, o zgrozo, wstępują w związki małżeńskie z ciemiężycielami. Nieznany autor wiersza Na warszawianki R. $i$ G. ${ }^{18}$ poddaje ostrej krytyce zachowania mieszkanek byłej stolicy, które na grobie ojczyzny, niepomne na zasługi i spuściznę duchową swoich ojców, braci i mężów, zapominając o honorze narodowym, rozniecają milość swymi wdziękami pośród zaborców.

Cyprian Godebski w wierszu Na odjazd Juliana Niencewicza do Ameryki (1803) ową naganną w jego mniemaniu skłonność do wyszumienia się w obliczu katastrofy uznaje za stałą cechę charakteru Polaków. W uszczypliwym porównaniu o barokowej proweniencji (z rozbudowanym, wielozdaniowym członem porównującym i podrzędnym jednozdaniowym porównywanym) zapewnia swego adresata o bezgranicznym oddaniu. Wśród wielu zestawień znalazł się m.in. następujący fragment:

\footnotetext{
15 Zob. W. Łoziński, Salon i kobieta. Z estetyki i z dziejótw życia towarzyskiego, Lwów 1921, s. 131-133.

16 Opisanie historyczno-statystyczne miasta Warszauy przez L. Gotębiouskiego, Warszawa 1927, s. 224.

17 Cyt. za: A. Kowalska Warszawa literacka w okresie przetomu kulturalnego 1815-1822, Warszawa 1961, s. 27.

${ }^{18}$ Rkps BN III 9556, k. 103-104.
} 
Pierwej, o czym nie można pomyśleć bez żalu,

Polak w klęsce powszechnej straci chęć do balu (...)

Niźli ten, co to kreśli, wielbić Cię przestanie ${ }^{19}$

19 C. Godebski, Dzieła wierszem i prozq..., wyd. K. Godebski, cz. 1, Warszawa 1821, s. 387.

Nie mylił się w swoich przypuszczeniach Godebski, bo oto po następnej wielkiej klęsce 1831 r. sytuacja powtórzyła się niemal z detalami. Gromi bawiące się z Rosjanami Polki Konstanty Gaszyński, dokonując tragicznej konfrontacji ich postaw z poświęceniem tych, którzy za ojczyznę oddali swe życie:

Táncujcie, Polki! Teraz czas tańcować

Z bohaterami Oszmiany, Warszawy!

Czego się smucić i czego żałować?

Dziękujcie Bogu, że mamy zabawy.

Tylko ostrożnie... żeby rączki wasze

Krwią się nie zlały o ich ramię wsparte,

Bo te mundury, te krwawe pałasze

Jeszcze z krwi braci waszych niestarte. (...)

Rkps BN III 6715 k. 84, rkps BJ 7572 IV - tytul: Wiersz rozrzucony $w$ sali $w$ czasie balu gubernatora Witta $w$ Warszawie $1832 r$. Inne tytuły wiersza: Rzeź oszmiańska; Do tańcujacych Polek z nieprzyjaciólmi ojczyzny. Bliższe informacje o utworze zob. E. Aleksandrowska, Problem zdrady na podstawie satyr i pamfletów "Na Polki balujace w czasach tragicznych dla ojczyzny” (1774-1832), [w:] „Bo insza jest rzecz zdradzić, insza dać się zludzic". Problem zdrady w Polsce przełomu XVIII i XIX wieku, red. A. Grześkowiak-Krwawicz, Warszawa 1995, s. 129.

Nie udało mi się ustalić czasu powstania ani autorstwa wiersza Do bawiących się Polek w' czas karnawalu, rkps BJ 7038, s. 78. Incipit wskazuje na związek z wierszem Gaszyńskiego, ale wiersz być może powstał wcześniej:

Tańcujcie, Polki, póki czas tańcować!

Gwiazdy salonu, wy zdobicie bale,

Gdy jednych braci poszedł wróg mordować,

Drudzy w kajdanach jęczą w kryminale.

Tańcujcie, Polki, w niewoli krainie,

Niech żadna w tańcu nie będzie ostatnią.

Cóż wam to szkodzi, że świat młody ginie?

Za was się ziemia czerwieni krwią bratnią.

Bawcie się, Polki, bawcie w życia wiośnie,

Szkoda, kto taką błogą chwilę traci,

Wszak plemię wasze do kajdan dziś rośnie,

Za was się ścielą groby waszych braci.

Tańcujcie, córki ojczyzny niegodne,

Bóg was ukarze za tak ciężkie grzechy.

Wróg wami wzgardzi, wy Polki odrodne,

Gdy dziś musicie dzielić z nim uciechy,

Bo takich zbrodni sam Bóg nie przebaczy,

Bawić się wtenczas, gdy gnębi wróg - zdrada,

Gdy braci naszych wiedzie krok rozpaczy,

Hasłem ich wolność lub wieczna zagłada. 
Podobne tony potępienia i ostrej krytyki spotykamy w liście menipejskim Mtodzież do dobrych Polek, zakończonym ostrzeżeniem:

$$
\begin{aligned}
& \text { Będziecie palcem wytknięte } \\
& \text { Jak hańba polskiej krainy } \\
& \text { I plemię, od was poczęte; } \\
& \text { Będą kajdan godne syny }{ }^{20} \text {. }
\end{aligned}
$$

Problem zdrady narodowej przez balujące Polki po upadku państwa podejmuje Afisz na reduty zapustne 1796 roku nawiązujący do znanego utworu Józefa Wybickiego. Dominują tu jednak przede wszystkim uczucia przerażenia i zgrozy na widok zabaw, w których Polki skaczą ze „smokiem swojego narodu” ${ }^{21}$. Ta postawa jest piętnowana jakby z dwóch perspektyw. Z jednej strony podkreśla się dla kontrastu niedawne nieszczęścia narodowe, $z$ drugiej roztaczana jest perspektywa szybkiego wynarodowienia, którego pierwszymi oznakami są gorszące zabawy ze sprawcami owych nieszczęść. Autor nie potrafi pogodzić się z myślą, że Polki wesoło bawią się z tymi, którzy nie tak dawno wkładali kajdany na ich rodaków, mordowali braci i ojców, hańbili krewne i siostry, profanowali świątynie, łupili majątki, podpalali miasta. Dlatego z perspektywy niemożności wyjaśnienia ich zachowań zapusty na grobie Ojczyzny łączy z blizej nie skonkretyzowanymi czynnikami irracjonalnymi ${ }^{22}$.

Do podobnej stylizacji zgrozy i hańby oraz obłąkania powróci Kajetan Koźmian w późniejszym nieco wierszu Do tańcującego Krakowa, w którym obydwa wątki przewijają się ze sobą, opatrzone dodatkowo kąśliwą ironią. W taniec jednak zostaje włączone całe społeczeństwo, przez co wiersz ten prekursorsko podejmuje znaczenie jednego $z$ kluczowych $w$ naszej narodowej symbolice motywu, znanego z późniejszych konkretyzacji w wielkich dziełach literackich: Dziadów (Bal u senatora), Wesela Wyspiańskiego, Oziminy Berenta, Balu w Operze Tuwima, Popiolu $i$ diamentu Andrzejewskiego. Taniec już więc tutaj kojarzony jest z irracjonalnym amokiem i opętaniem, z satanistycznym występkiem i kainizmem, brakiem sumienia i wrażliwości:

Kiedy los, sprzysiężony na kraju ruinę, Smutną przeznaczeń Polski dobija godzinę, Gdy z ostatniego szczątka ojczystej uchrony Wyparty mężny rodak w obce zmierza strony, Gdy nie masz, kto by nas mógł, kto by chciał zasłonić, Było komu kraj niszczyć, nie ma komu bronić. Co za szczęśliwy powód do uczt i do tańców! Skaczą żony i córki niebacznych mieszkańców,

${ }^{20}$ Cyt. za: E. Aleksandrowska, op. cit., s. 121.

${ }^{21}$ Ibidem, s. 122.

22 Zob. rkps BJ 7042, k. 64 (strofa druga). 
Skaczą rycerze, skaczą pierwsi urzędnicy, Skaczą w domach i ledwie już nie na ulicy. Dają nam brawo obcy i każą grać daléj, Zawsze tak Polak skakał, jak mu oni grali. Od walca i kadryla zaczął się bal w kraju, A kończy się kozakiem, jak było w zwyczaju, I choć może niedługo potrwa skok ostatni, Są tancerze do pierwszych, są do drugich zdatni. Sama zalotna Egle, by kto był ochoczy, Przecudnie po kadrylu kozaka wyskoczy. O, dzięki ci, wyborne Polek wychowanie! Polska ginie... tańcujmy, póki czasu stanie, Tańcujmy i nie myślmy, co nastąpi potem, I skończmy godnie scenę płochych głów zawrotem.

Nie masz, płci piękna, żadnych do smutków powodów, Taniec ma swoją wziętość u wszystkich narodów. I, czy Moskal, czy Niemiec tę ziemię posiędzie, Zniszczy język i prawa, lecz walcować będzie; Ja nie mogę nie westchnąć, że wśród Polek grona Widzę dzieci skaczące, kiedy matka kona ${ }^{23}$.

W tych nagannych zachowaniach partycypowały jednak nie tylko przedstawicielki zamożniejszych rodów szlacheckich czy arystokracji. Jeden z pamiętnikarzy wspomina pewną mieszczankę, która ku publicznemu zgorszeniu miała w zwyczaju bawić się wesoło z pruskimi oficerami i pokazywała się z nimi na ulicach. Pannę tę zrazu ostrzegano anonimowymi listami, że jeśli będzie kontynuowała ów proceder, spotka ją zasłużona kara. I rzeczywiście, wkrótce szpetnie obcięto jej piękne warkocze, zostawiając na ulicy „łysą” z „pękatym puklem włosów" w dłoniach. Jak wnosić można z kolejnych kart pamiętnika, w wielu miejscach Warszawy rozklejano ulotki z ostrzeżeniami, że która kobieta „zada się" z Prusakiem, będzie miała obcięte włosy, co zdaje się potwierdzać przypuszczenie, iz przypadki powiązań Polek $z$ zaborcami nie należały wcale do rzadkich ${ }^{24}$. I zapewne wyjątkową w wyższych sferach musiała być postawa, jaką na balu wydanym w Grodnie przez Repnina zajęła „piękna Gorecka”, która na zapytanie feldmarszałka, dlaczego unika zabawy i tańców, zalawszy się łzami odpowiedziała:

Czegóż WPan chesz, ażebym na pogrzebie matki mojej, ojczyzny, tańcowała ${ }^{25}$.

${ }^{23}$ K. Koźmian, Do tańcującego Krakowa, [w:] K. Koźmian, Różne wiersze, Kraków 1881, s. 76.

24 W. Zambrzycki, Pamiętnik Filipka, Warszawa 1957, s. 173, 176.

25 F. Karpiński, Historia mego wieku i ludzi, zktórymi żytem, opr. R. Sobol, wyd. E. Aleksandrowska i Z. Goliński, Warszawa 1987, s. 175. 
Szczególną sympatią u Polek ze względu na organizowanie zabaw i osobiste w nich uczestnictwo cieszył się gubernator Warszawy, Koehler, który według Stanisława Szenica był „ojcem psuj-dzieckiem dla rozkiełzanych paniczów i panienek" ${ }^{\text {,6 }}$. Maria Radziwiłłówna wspomina, że podczas takich imprez „dokonywała się unia Prus z Polską”. Za to też kochali go warszawianie tak serdecznie, że mu pomnik chcieli wystawić po wyjściu Prusaków. Nie obyło się bez literackich peanów na jego cześć. Marcin Molski porównuje okres jego rządów do szczęśliwości Rzymu za Trajana, podkreślając szczególnie wyjątkową zdolność gubernatora w „oswajaniu” wolnych niegdyś Polaków z „kajdanami”:
Jeżeli pod Trajanem lud szczęśliwy w Rzymie
Nadał mu nieśmiertelne dobroczyńcy imię,
Jeśli Fryderyk Wilhelm, w dziejach Wielkim zwany,
Od wdzięcznego narodu był za to kochany,
Iż na dobro poddanych pierwsze mając względy,
Złych usuwał, cnotliwym powierzał urzędy,
Królu! do serc Polaków podobne masz prawa,
Czuje wybór Koehlera wdzięczna ci Warszawa.
On cię nowym przed nami wystawia Trajanem,
Niegdyś wolnych, oswaja z podległości stanem,
A rozsądkiem, dobrocią i wpływem kredytu,
Umie zacierać pamięć dawniejszego bytu ${ }^{27}$.

Oficerowie, mając ze strony Koehlera przyzwolenie i osobiste poparcie, chętnie korzystali ze sposobności bawienia się z Polkami.

Trzeba było widzieć - wspomina pamiętnikarka - te zabawne figury z zaokrąglonymi łokciami, połową ciała naprzód wygiętą i kołysającą się w ten sposób, że ich akselbanty wybijały oczy tancerkom... ${ }^{28}$

Proceder ów był daleko częstszy niż mogłoby się wydawać, i to już począwszy od targowicy, kiedy wiele dam zatroskanych o swoją przyszłość romansowało bez żadnych wewnętrznych oporów z zaborcami. Spośród arystokratek niewiele było wówczas także

\footnotetext{
${ }^{26}$ S. Szenic, Bratanek ostatniego króla, Warszawa 1983, s. 209.

${ }^{27}$ Do J. W. Koehlera, gubernatora miasta Warszaury $w$ dzién imienin dnia 11 listopada 1801 r., [w:] Pisma Marcina Molskiego z pośmiertnych rękopismów zebrat Wiktoryn Radliński, seria II, Warszawa 1865, s. 340.

${ }^{28}$ Ibidem, s. 250. Czytamy tu m.in.:

Nie był on jednak czym innym, jak narzędziem - może tylko bezwiednym - swojego rządu, który go stale utrzymywał na jego posadzie właśnie dlatego, że mu te pijatyki i rozpusty młodzieży, i te nieustawiczne salonowe zabawy, thumne bale, pikniki, przebierania się, amatorskie teatry, zbytki różnego rodzaju, które kwitnęły pod jego zarządem, bardzo były po myśli, patrzał on na nie $z$ dala szyderczym okiem, przekonany, że to ciągłe biesiadowanie panów i szlachty polskiej na grobie ojczyzny będzie epilogiem naszych dziejów, zgubą ostateczną majątków, ducha, narodowości polskiej.
} 
chlubnych wyjątków. Świadek tych wydarzeń, Jan Dembowski, pisał do Ignacego Potockiego w liście z 5 lutego 1794 roku:

Damy nasze szalały z Moskalami prawie aż do wstydu... te panie, co w początkach uciekały od Moskali, teraz rozum gubią za nimi. Co tylkojest poczciwych Polaków, z żalem i smutkiem spoglądają na takie postępowanie ${ }^{29}$.

Co ciekawe, wejść do towarzystwa kobiet „tańczących na grobie ojczyzny” nie było sprawą wcale łatwą. Franciszek Gajewski pisze, że panie przybyłe z prowincji czyniły różne zabiegi, aby dopuszczono je na bal lub wieczór „dany przez jajkiegokolwiek członka tej klasy wyborowej”30.

Najgłośniejsze były przypadki, gdy Polki po rozbiorze kraju opuszczały swoich mężów i wychodziły za Rosjan. Tak uczyniły m.in.: Protowa z Lubomirskich Potocka, jej córka Kalinowska i siostra Walewska z Lubomirskich, Karolina z Rzewuskich Sobańska. Ów rodzaj apostazji narodowej szczególnie ostro piętnuje Helleniusz, według którego w ciągu zaledwie trzech lat w samym środowisku tulczyńskim podpisano $z$ tego powodu dziesięć rozwodów:

Polki, bogatsze panie, szlachcianki, wykradały się za Moskali z domu rodziców, rozwodziły się z mężami, oddawały w ręce rosyjskie majątki znaczne, a potem najnieszczęśliwsze, znienawidzone od mężów, litości nawet w nich za ślepą miłość swoją wzbudzić nie mogły. Ile ich było, smutno jest wspomnieć, lepiej ich imiona zamilczeć. Zdrada wykonana przez tych, którzy nieprzyjaciół do kraju sprowadzali, ich wzywali, dopełnioną i dokończoną została przez zdradę polskich niewiast, tym boleśniejszą, że pięknością i przymiotami swymi na szlachetniejszą rolę w życiu, na los lepszy zasługiwały ${ }^{31}$.

Zresztą w ogóle opinia publiczna zdecydowanie potępiała zabawy z zaborcami, te zwłaszcza, które były organizowane przez nich samych, jak również wszelkiego rodzaju z nimi stosunki i powiązania, i żadnych środków lagodzących tutaj nie stosowano, nawet jeśli ceną owego uczestnictwa $\mathrm{w}$ nich było ocalenia majątku rodzinnego czy możliwość interwencji w jakiejś ważnej sprawie. Oburza się Piotr Jaxa Bykowski na księcia Narbutta, który frymarczy wdziękami swej żony i córki, próbując nimi zastawić sidła na samego Repnina ${ }^{32}$. Złorzeczą zaraz szersze kręgi skłonności do „wyszumienia się” Polacy starej daty, pamiętający jeszcze niewinne sarmackie asamble i korwety. Starosta dymirski, Golejewski, znany na Kijowszczyźnie z archaicznie wygolonej głowy, zawiesistego wąsa i przysłowia „quinque diabłów”,

\footnotetext{
${ }^{29}$ Tajna korespondencja $z$ Warszauy do Ignacego Potockiego, 1792-1794, opr. M. Rymszyna, A. Zahorski, Warszawa 1961, s. 317. Podobne obserwacje poczynił Seweryn Bukar w swych Pamiętnikach, Drezno 1871, s. 92:

Rozbroiły się już i serca dam naszych niektórych, otworzyły się bale, na których wywijały nasze patriotki z Moskalami.

${ }^{30}$ F. Gajewski z Błociszewa, Pamiętniki... pulkownika wojsk polskich (1802-1831), opr. S. Karwowski, t. 1, Poznań, b. d., s. 17-18.

${ }^{31}$ (E. Iwanowski) Helleniusz, Pamiq̨tki polskie z różnych czasów, t. 2, Kraków 1882, s. 246.

${ }^{32}$ P. Jaxa Bykowski, op. cit., s. 22-23.
} 
dowiedziawszy się, że jego najstarszy syn, Józef, całe dnie z dala od domu spędza na grze w faraona i ucztach z szampańskim winem, że kocha się w mężatkach i trwoni jego majątek, wysyła kozaka Zawieruchę z surowym poleceniem przywiezienia „deputata”. Gdy ten zmęczony drogą usiłuje przywitać ojca staropolskim padnięciem do nóg, starosta nakazuje służącym, aby „rozciągnęli” go na kobiercu i wyliczyli mu sto „łóz odlewnych”. „Na krzyk straszny, gdy córka przyleciała ojca błagać, rózgami otrzymała odpowiedź”33.

Na katastrofę narodową nakładała się związana z nią osobista tragedia, jakiej doświadczyła pewna szlachecka rodzina $z$ Wołynia, w której jedna z pań ku hańbie familijnej i towarzyskiej weszła potajemnie w związek małżeński z moskiewskim oficerem. Imć Błoszczyński o decyzji siostry i o reperkusjach z nią związanych powiadamia w liście swojego brata, prosząc, aby wsparł go dobrą radą w tej kłopotliwej i obciążającej rodzinę sytuacji:

Tak się uwzięły nieszczęścia na nas od niejakiego czasu, iż prócz przypadków mieszających spokojność, wydzierających majątek, nic sobie więcej donieść nie możem. Do tej powszechnej na cały naród klęski, która każdego boleścią przejmuje serca, do tych pokilkakrotnych zdarzeń szczególnie nas dotykających, podobało się Najwyższemu nowe świeżo zesłać na nas udręczenie wydarciem nam siostry, które niemałą plamę familii naszej przynosi.

Konsystujący w Ortelu kapitan Trehubow niedocieczonymi sposobami znalazłszy wstęp do serca miętkiego p. Heleny za pomocą rajfurki służącej jej, upatrzywszy sposobną porę z niedzieli na poniedziałek i przybywszy do Dołhy, folwarku w Międzyżyczyźnie, wziął ślub od popa schyzmatyckiego. Tak się to cicho wszystko zrobiło, iż i nikt poznać nie mógł tej intrygi i wszyscy spali, kiedy uprojektowany przyprowadzali do skutku zamiar. Później dowiedziawszy się, iż determinacją była strzelać, gdyby za przebudzeniem się którego znalazł, obronę słusznie przypisać należy łasce Boga, iż wszystkich nas uśpił $\mathrm{w}$ tę porę, bo pewnie by którego $z$ nas śmierć spotkała.

Po szlubie przyjeżdżał major Suchow z tegoż batalionu co i kapitan, z przeprosinami, ale znalazłszy Imość dużo dotknioną tym przypadkiem, nie mogąc nic wskórać natrętną swą prośbą, odjechał zlajawszy dwudziestoletniego rekruta, mnie najszczególniej, mieniąc być sprawcą tego nieubłagania. Pomimo różnych odgrażań, z którymi się oświadczył, już zaczął dziś wywierać skutek swej zemsty przysławszy do folwarków koni z półtorasta na wypasienie łąk najlepszych. Bojąc się, aby z nas które mu osobistej nie przyszło ponieść krzywdy, (a) Imość słabą znacznie oddalić od widoku tego fatalnego miejsca, postanowiliśmy ujechać do Sutna lub Ujagłowa na jaki czas, chociaż i na tym dużo cierpieć będziemy w czasie teraźniejszym, gdzie zniszczenie wszędzie się uczuć daje (...)

${ }^{33}$ (E. Iwanowski) Helleniusz, Wspomnienia lat minionych, Kraków 1876, s. 387-389. 
Zakończywszy tego obmierzłego zdarzenia narrację, nie zostaje mi, jak oświadczyć prośbę, abyś światłą swą radą wesprzeć raczył, jakiego by nam należało chwycić się środka, który by był zdolnym ujęcia się za uczynioną tą krzywdę ${ }^{34}$.

Józef Krasiński, oboźny i kasztelan w czasach Królestwa Kongresowego, porównując pokolenie młodzieży romantycznej z młodzieżą, która doświadczyła tragedii rozbiorów, wystawia tej drugiej niezwykle surową ocenę.

Młodzi ludzie dzisiejsi — pisze w swych pamiętnikach — wydaj mi się aniołami po młodzieży mojego pokolenia. Jej zabawą i zatrudnieniem były: pijatyki, gry, burdy, kłótnie i pojedynki (...) I jest rzeczą pewną, że od tej zabawy ogólnej nikt $\mathrm{z}$ bogatszej młodzieży nie wyłamywał się ${ }^{35}$.

Dodaje przy tym, że Polacy, zdemoralizowani gorzej niż Sodomici, psuli się i gangrenowali aż do szczętu, co z pewnością było na rękę zaborcom i prowadzonej przez nich polityce wynarodowienia. Wydawać by się więc mogło, że rozbiory zburzyły nie tylko państwo, ale również morale klas przywódczych. Ostatecznie jednak — zauważa Piotr Wandycz - ów „taniec upiorów” na gruzach Rzeczypospolitej okazal się tylko krótkim epizodem ${ }^{36}$, i niedługo potem najbardziej niepoprawni hulacy stawali w szeregach żołnierskich, aby u boku cesarza Francuzów realizować aspiracje Polaków do wybicia się na niepodległość.

\title{
II. Żałoba po stracie Ojczyzny i jej „przepracowanie” w literaturze porozbiorowej
}

\author{
Finis Poloniae - \\ może $w$ dzień deszczowy, niezbyt przyjemny, \\ jednak w powyższym przypadku szmer szczęścia, \\ a potem solo na rogu, \\ i jeszcze hortensja, najcichszy kwiat, \\ który do listopada przetrwa na deszczu, \\ cicho na grób.
}

\section{Gottfried Benn}

I. Na żałobę skladają się psychologiczne procesy uruchamiane przez stratę wiążącego emocjonalnie i intelektualnie obiektu, których ostatecznym celem jest zapomnienie. Występują one w kilku charakterystycznych fazach. Najwcześniejszą z nich, pojawiającą się bezpośrednio w obliczu śmierci lub innej znaczącej utraty, jest odrętwienie, którego zasadniczymi

\footnotetext{
${ }^{34}$ List $z 13$ maja 1795 roku z Ortela, rkps Ossol. 2872 II, k. 161-162.

35 Zob. J. Falkowski, Obrazy z życia kilku ostatnich pokoleń w Polsce, t. 1, Poznań 1877, s. 119-120.

${ }^{36}$ P. Wandycz, Pod zaborami. Ziemie Rzeczypospolitej w l. 1795-1918, tł. W. Zajączkowski, Warszawa 1994, s. 44.
} 
przejawami są takie przeżycia jak: szok, zaskoczenie, porażenie, niedowierzanie, poczucie absurdu (A). W następnej fazie dominującym objawem jest depresja (ostra żałoba z symptomami żalu, smutku, rozpaczy, poczucia winy, pretensji, gniewu), ściśle związana z różnymi postaciami lęku i poczucia zagrożenia, wywołującymi boleśnie ciążącą niezdolność do rozpoczynania lub kontynuowania istniejących poprzednio sposobów zachowania i pełnienia ról społecznych. W okresie tym, nazywanym w literaturze fachowej fazą dezorganizacji, wytwarzają się warunki ostatecznego zerwania z utraconym obiektem przy dojściu do stanu wewnętrznej pustki i równoczesnego odczucia, że pomimo utraty i nieobecności tego obiektu świat istnieje nadal, chociaż w postaci zdegradowanej znaczącym brakiem (B). W trzeciej fazie, reorganizacji, następuje przygotowanie do zawarcia nowych związków, wskutek czego nieobecność zmarłego zostaje zaakceptowana jako fakt nieodwracalny $(\mathrm{C})^{37}$.

Żałoba jest więc formą myślowego i uczuciowego zacierania się poczucia absurdu wobec śmierci, gdy nie można już dłużej zaprzeczać realności „ostatecznego”. Charakteryzuje się pewną dynamicznością rozwijającą się w czasie w postaci wymieniających się faz dezintegracji i integracji: odłączenia więzi z utraconym obiektem, przystosowania do środowiska pozbawionego tego obiektu, tworzenia nowych relacji. „Przeżałowanie straty” (decathexis), będące jej celem, polega na uwewnętrznieniu katastrofy, co stanowi podstawą dla „odłączenia pamięci” od niej oraz jej przepracowania i ponownego przeżycia, aby więź z obiektem wymienionych procesów uległa ostatecznie rozluźnieniu poprzez pogodzenie się z losem.

Jak wskazuje Antonina Ostrowska ${ }^{38}$, w żałobie obiekt ów nie zostaje całkowicie wyparty z myśli i uczuć, jednak typ więzi z nim ulega zmianie na tyle, że pozwala na wytworzenie się nowej orientacji w stosunku zarówno do zmarłego, jak i tych osób i warunków, które będą mogły go zastąpić. Żałoba dokonuje się więc w oparciu o relację: człowiek - świat zewnętrzny. Początkowo w wyniku straty związek ten ulega gwałtownemu zerwaniu, czego rezultatem jest zwrócenie się ku własnemu wnętrzu, gdzie w wyniku procesów interioryzacyjnych tworzą się schematy nowych współzależności ze światem.

\section{A. Odłączenie}

Upadek państwa stanowi jedną z najbardziej wyraźnych cezur historycznych w naszych dziejach, przy czym nie chodzi tutaj jedynie o stronę faktograficzną tego wydarzenia, wy-

${ }^{37}$ I. Namysłowska, Żaloba, „Psychiatria Polska” 1976, z. 2, s. 179-185.

${ }^{38}$ A. Ostrowska, Smieŕ́ $w$ doświadczeniu jednostki i spoteczeństwa, Warszawa 1991, s. 209. W innym miejscu autorka proces decathexis charakteryzuje w sposób następujący: „Gdy ktoś przeżywa znaczącą stratę, jednym ze sposobów uporania się z nią jest zanegowanie, zaprzeczenie faktu, że się zdarzyła. Aby uniknąć przykrego uczucia towarzyszącego uświadomieniu sobie nieodwracalności tej straty, osoba w żałobie często kreuje w myślach wizerunek zmarłego, z którym ciągle pozostaje w mniej lub bardziej symbolicznych interakcjach. Stopniowo, pod wpływem akceptacji faktów z rzeczywistości następuje także akceptacja faktu, że obiekt uczuć nie istnieje. Tak więc wszystkie uczucia, myśli, wspomnienia, oczekiwania, które wiązaly osobę przeżywająca żałobę ze zmarłym, są powoli przepracowywane, ponownie przeżywane, aby wreszcie ulec rozluźnieniu". (A. Ostrowska, Śmierć i umieranie, Warszawa 1991, s. 102). 
mierną ze względu na konsekwencje prawno-administracyjne. Przełomowość w tym przypadku sięga głębiej, z granicą daleko bardziej subtelniejszą i mniej uchwytną dla metod statystycznych, przebiegającą przez cały splot uwarunkowań natury psychicznej i świadomościowej, i jako takich pozostawiających trwały ślad w ówczesnych biografiach.

Po okresie wyczekiwania i niepewności co do losów ojczyzny, trwającym około dwu lat, od drugiego do trzeciego rozbioru, patriotycznie nastawiona część społeczeństwa została porażona wymykającymi się spod jej kontroli faktami, w wyniku czego po upadku państwa obserwujemy wyraźny regres i zastój w życiu umysłowym narodu. Ów okres martwoty, apatii, krańcowego zniechęcenia zamykany jest w różnych granicach czasowych. Niektórzy pamiętnikarze uważają, że trwał on od dwu do trzech lat, do chwili, gdy pogrążone w żałobie i wyludnione ośrodki, na czele $\mathrm{z}$ dawną stolicą, poczęły się ożywiać i na zasadzie odreagowania ich mieszkańcy w sposób szaleńczy rzucili się w wir zabaw, uciech, pijaństwa, wyuzdania, pozwalających im zapomnieć o doświadczonej niedawno katastrofie i nieszczęściu. Inni pisarze przesuwają datę końcową tego znamiennego zbiorowego letargu na rok 1800, kiedy to pojawiają się pierwsze inicjatywy mające na celu ratowanie polskości przed jej ostatecznym ujarzmieniem. Z kolei Feliks Bentkowski analizując sytuację literatury po 1795 roku już w 1814 roku, kiedy to wyszła jego Historia literatury polskiej, wyodrębniał dwunastoletni okres po trzecim rozbiorze, będący jego zdaniem tragiczną i gwattowną przerwą w rozwoju naszej literatury, przy czym za główne źródło tego stanu rzeczy uznał ograniczenie wolności słowa oraz wypieranie polszczyzny przez języki państw zaborczych ${ }^{39}$. Inaczej rzecz ujmuje Marian Dubiecki stwierdzając, że po wyjeździe króla z Warszawy cisza i bezwład trwały zaledwie trzy lata, po czym rozpoczął się kilkunastoletni okres przejściowy, będący kolebką nowych kierunków i przewartościowań w naszej literaturze ${ }^{40}$. Potwierdzenie tej opinii znajdujemy u Franciszka Skarbka, zwracającego dodatkowo uwagę na źródła owej martwoty:

W pierwszych trzech latach po zajęciu kraju przez Prusaków była Warszawa jak dom z powodu śmierci ojca familii i pana domu od wszystkich ukochanego świeżą żałobą pokryty. W domu takim jest wszędzie cicho i ponuro, a wszędzie pełno wspomnień na tego, którego opłakują. Każdy z pozostałych tłumi żal w sobie samym, kryje się przed innymi, o zgasłym tylko myśli, a nie wspomina o nim nikomu, aby obopólnego nie powiększać zalu. Chciałoby się jeszcze wątpić o jego zgonie, a gdziekolwiek rzuci okiem, widzi, że go brakuje ${ }^{41}$.

Z kolei na psychologiczne podłoże tych gwałtownych zmian świadomościowych wskazuje Wlodzimierz Spasowicz, kierując uwagę na kontrast między znaczącą przerwą w roz-

${ }^{39}$ F. Bentkowski, Historia literatury polskiej, t. 1, Warszawa, Wilno 1814, s. 175.

${ }^{40} \mathrm{M}$. Dubiecki, Historia literatury polskiej na tle dziejów narodu skreslona, t. 2. Warszawa 1888. A. Jougan ów zastój w literaturze łączy z analogicznymi zjawiskami w życiu publicznym i politycznym. Zob. A. Jougan, Ksiądz prymas Woronicz. Monografia, cz. 2, Lwów 1908, s. 51.

${ }_{41}$ F. Skarbek, Pamiętniki Seglasa, Warszawa 1959, s. 126. 
woju literatury polskiej a rewolucyjnymi dokonaniami w tym samym czasie w obrębie kultury i polityki na zachodzie Europy:

Ludzie, złączenie poczuciem wspólnej narodowości, utracili właściwą sobie sferę społeczną i znaleźli się wpośród zupełnie obcych żywiołów. Nieprędko oni poczęli się zastosowywać do nowych warunków i w nowe skupiać związki. Zrazu nastąpiła jakby przerwa w ograniczonych funkcjach życia - tak, iż w dziejach piśmiennictwa powstaje dość długi zastój, niby szara smuga, oddzielająca chwilę upadku politycznego od początków odrodzenia literatury. W okresie tym przejściowym zjawiska literackie nieliczne są i ubogie; ale w świecie europejskim dokonują się przewroty olbrzymie, znamionujące epokę rewolucyjną i napoleońską 42 .

Powyższe konstatacje historyczne odnoszące się do stanu umysłowego Polaków po 1795 roku zostały potwierdzone przez wyniki współczesnych badań, np. dane liczbowe dotyczące produkcji wydawniczej końca XVIII wieku wyraźnie wskazują, że w stosunku do początku lat dziewięćdziesiątych liczba wydawnictw po 1795 zmniejszyła się prawie trzykrotnie, a w szczególnym przypadku w roku 1798 aż dziewięciokrotnie ${ }^{43}$. W tym samym czasie zmniejsza się prawie dwukrotnie ilość prasy periodycznej. Rozgadane czasy stanisławowskie, na których wielomówstwo i grafomanię wielokrotnie skarżył się Krasicki, a także inni pisarze tego okresu ${ }^{44}$, zstępowały więc niemal z dnia na dzień w bezgraniczną otchłań bólu patriotycznego i milczenia.

Pokolenia, które doświadczyły upadku Rzeczypospolitej, były naznaczone piętnem wyjątkowego dramatyzmu, albowiem równocześnie niemal doznawały szczytów wzlotu i upad$\mathrm{ku}$, entuzjazmu i rezygnacji, rozbudzonej nadziei i rozpaczy. Zmuszone były w związku

${ }^{42}$ W. Spasowicz, Dzieje literatury polskiej. [tł. S. Czarnowski i A. G. Bem], opr. A. G. Bem, Kraków 1891, s. 234.

${ }^{43}$ Zob. M. Czarnowska, Ilościowy rozwój polskiego ruchu wydawniczego 1501-1965, Warszawa 1967, s. 172-173.

Władysław Prokesch w artykule Nieznane perty polskiej poezji patriotycznej pisze m.in.: „Przez 5 lat, od 1795 do 1800 roku, żadna ważniejsza, lepsza, albo przynajmniej zajmująca i doceniona ksiązka nie wyszła w Warszawie, nie obudziła chęci do czytania i piśmiennictwa. („Kurier Warszawski” 1921, nr jubileuszowy, s. 72).

${ }_{4}^{4}$ W jednym z ostatnich swoich wierszy z 1792 roku Józef Koblański w związku z tą kwestią wypowiada się następująco:

Z wolna, bracia w Apollinie,

Niech Muz polskich lustr nie ginie.

Miejcie za statut najpierwszy:

Więcej poetów, mniej wierszy.

Piękne Muzy mają nogi,

Ich językiem mówią bogi,

A my czasem jak gadule

Brédzim wiersze w kanikule.

Nie gadają tak w zapale

Ani szalonych szpitale.

(Mój zal)

Wiersze Józefa Koblańskiego i Stanisława Szczęsnego Potockiego — zapomnianych poetów Oświecenia, opr. E. Aleksandrowska, Wrocław 1980, s. 101. 
z tym do podejmowania częstych wyborów obywatelskich, opowiadania się po którejś ze stron. Owo zaskakiwanie przez wydarzenia i brak orientacji w zagęszczonej atmosferze politycznej sprzyjały ambiwalentnym postawom, niekonsekwencji, częstym zmianom opcji. Nie dziwi więc zbytnio fakt, że zwolennicy i entuzjaści Konstytucji Trzeciego Maja w 1792 roku masowo przystępowali do targowicy (deklarując, iż uznają sejm czteroletni i wszelkie jego czyny za despotyczne, a przełaskawą Katarzynę i konfederację za zbawienne), co później nie przeszkadzało im wstępować w szeregi kościuszkowskich insurgentów. Z kolei w czasie gdy sejm ratyfikował rozbiory, Grodno, ku oburzeniu nielicznych, w tym urzędników rosyjskich, upajało się wystawnymi przyjęciami, balami, zabawami. Uczestnicy insurekcji tłumnie wypełniali świątynie podczas nabożeństw homagialnych, odżegnując się od jakichkolwiek związków z Kościuszką i jego stronnikami.

W dramacie owych wyborów ostatnia odsłona, trzeci rozbiór, na długie lata zawiesiła „ciąg dalszy".

Po wrzawie rewolucyjnej — pisze Kajetan Koźmian — po zapałach, nadziejach, obawach, po chwilowej, acz zmąconej swobodzie nastąpiła pogrobowa cisza ${ }^{45}$.

\section{B. Przystosowanie (dezintegracja)}

Konsekwencje porażenia rozbiorami i upadkiem państwa były bardzo głębokie. Niezwykle cennym dokumentem i świadectwem pozwalającym je rekonstruować są wiersze i poematy powstałe bezpośrednio po upadku państwa. Stanowią one doskonały materiał do przebadania zmian i przewartościowań, jakie dokonały się w obrębie obowiązujących wówczas struktur nazywania, wyjaśniania i oceniania świata oraz człowieka. Ich znaczenie zaś przy rekonstrukcji tego rodzaju świadomości jest szczególne, przede wszystkim z uwagi na to, że akt kreacji i fikcja literacka zostają w nich zredukowane do minimum na rzecz mimetyzmu wobec rzeczywistości tak zewnętrznej, jak i wewnętrznej. Można je w związku z tym potraktować jako pamiętnik cierpień obywatelskich, jeśli uwzględni się fakt, że te same stany opisane zostały w takich formach piśmienniczych jak: wspomnienia, korespondencja, przemówienia, odezwy. Literatura ta, nierzadko heterodoksyjna wobec klasycystycznych zasad i reguł poezjotwórczych, jest wyjątkowym dokumentem swoistego procesu, w którym pisanie egzorcyzmuje w pewien sposób urazy i koszmary wewnętrzne za pomocą ich obiektywizowania i wyrzucania poza tereny neurotyczne. Pozwala w związku z tym zaobserwować nadzwyczaj interesujący a dramatyczny proces, w toku którego ludzie inspirowani dotąd problemami bezosobowymi, systemowymi, często abstrakcyjnymi, porażeni upadkiem Ojczyzny, zwracają się do swojego wnętrza, zaczynają rozmyślać o własnej podmiotowej istocie, o swoich przeżyciach, stanach i reakcjach psychicznych, wyłączonych dotąd z obszaru literatury. Prze-

\footnotetext{
${ }^{45}$ K. Koźmian, Pamiętniki, opr. J. Willaume, M. Kaczmarek, K. Pecold, wst. A. Kopacz, t. 1, Wrocław 1972,
} s. 269. 
szedłszy wszystkie szczeble drabiny wewnętrznego piekła swoim konstatacjom nadają wymiar jednocześnie subiektywny i uniwersalny.

Eksterioryzacja tematów urazowych w liryce tej dokonuje się przede wszystkim w oparciu o metaforyzację i literackie opracowanie własnych obserwacji. Wyselekcjonowane zostają te ich przejawy, które współgrają z odczuciami obserwującego, bądź są przez nie filtrowane, a w nielicznych przypadkach także porządkowane. Można przypuszczać na przykład, że Adam J. Czartoryski w losy, zachowania i wypowiedzi bohaterów swojego poematu wpisał własną sytuację, przeżycia i doświadczenia pierwszych dni niewoli narodowej. Podobnie ma się rzecz z innymi tekstami, a zwłaszcza wierszami więziennymi, w których narracja i wyznanie są funkcją bezpośrednio doświadczonego nieszczęścia i maksymalnie przyblizająje do rzeczywistości pozaliterackiej. Przeżywający i obserwujący podmiot tych utworów zaciekle broni własnych, opartych na rzeczywistych przeżyciach i spostrzeżeniach, fikcji, sprawiając wrażenie paradoksalnego reagowania, gdyż wywołują one w nim ból, pogrążają w rozpaczliwym przerażeniu, czyniąc jego egzystencję męczarnią. Projekcją takich zapewne odczuć autorskich są „(..) wszędzie gorzkie w oczach placze, W ustach lamenta, na twarzach rozpacze" (J. Morelowski, Tren I, ww. 33-34) ${ }^{46}$, czy też starcy jęczący na podsieniu i sędziwe prababki przeklinające swe córki za to, że wydały na świat zdrajców, rozszlochane dziewice targające swe warkocze (J. P. Woronicz: Hymn do Boga) ${ }^{47}$, których podmiot tych wierszy, właściwie z uwagi na swoją konstrukcję psychiczną ten sam we wszystkich tekstach, spotyka na swojej rzeczywistej bądź wyimaginowanej drodze. Irracjonalne doznania graniczą ze stanami niemal chorobowymi, gdy przeobrażają się w popęd destrukcji, np. w rozpaczliwym wezwaniu wystosowanym do polskich matek ustami legendarnej Wandy o śmierć w jednym pokoleniu czy w słowach skierowanych przez podmiot Trenu VII Józefa Morelowskiego do Niewinności i Astrei:

Mówcie piorunowładcy: niech raczej w ruinie

Świat zagrzebie, a winny i niewinny ginie.

(ww. 21-22) ( $^{4}$.

Podobną uwagę, wyrażoną w formie postulatu, znajdujemy w liście z 17 maja 1794 roku Ignacego Krasickiego skierowanym do hr. Lehndorffa:

Nie ródźmy dzieci, Przyjacielu (...) nie warto zaludniać tego wstrętnego świata ${ }^{49}$.

\footnotetext{
${ }^{46}$ Wiersze Józefa Morelowskiego, wyd. i wst. opr. E. Aleksandrowska, Wrocław 1983 (Zapomniani Poeci Oświecenia 2), s. 32.

${ }^{77}$ J. P. Woronicz, Pisma uybrane, wst., wyb. i koment. M. Nesteruk i Z. Rejman, Warszawa 1993, s. 282.

${ }^{48}$ Wiersze Józefa Morelowskiego, op. cit., s. 40.

${ }^{49}$ I. Krasicki, Korespondencja, z papierów L. Bernackiego wyd. i opr. Z. Goliński, M. Klimowicz, R. Wołoszyński pod red. T. Mikulskiego, t. 2, Wrocław 1958, s. 641.
} 
Uświadomienie sobie faktu nieistnienia Rzeczypospolitej urealniło przekonanie, że wszelkie relacje $z$ nią zostały na zawsze przerwane. Zygmunt Freud stan psychiczny wynikający z takiego uświadomienia nazywa „melancholią żałobną”. Charakteryzuje się ona ambiwalencją skrajnych uczuć, poczuciem pozbawienia wartości i poniżenia przez stratę ${ }^{50}$. Przy podobnym porażeniu człowiek wpada w chaos emocji, myśli, koncepcji, których nie potrafi uporządkować, ani nie jest w stanie dokonać wśród nich żadnego wyboru. Wszystko staje się w związku z tym relatywne, wydziedziczone $z$ uniwersum, wyższych zasad i sensów, ukierunkowania na jakikolwiek cel oraz treści znaczące. Rozbiciu ulegają aksjomaty, kanony i imponderabilia, wszystko pochłania „Moloch historii”, nawet najbardziej wyabstrahowane pojęcia. Życie zostaje „zgniecione” do postaci katastrofy, nieszczęścia, bezgranicznego bólu. W takiej sytuacji człowiek zdolny jest do każdego czynu, każdego słowa, nawet obwarowanego najbardziej nieprzenikalnym murem tabu. Absurd pozwala mu na wolność od wszystkiego i do wszystkiego, ponieważ wszystko jest wątpliwe, podyktowane przypadkiem i kaprysami historii, a nie zależy od jakiś nadrzędnych zasad czy świadomego działania ludzi.

Wspomniana destrukcja w postaci myśli o samobójstwie narodu czy o zagładzie całego gatunku ludzkiego jest w kontekście sytuacji politycznej po 1795 roku symptomem zawieszenia czynności popędu konstrukcji. Józef Wybicki wielokrotnie kondycję duchową Polaków po 1795 roku kojarzy z „Zarażeniem śmiercią”51. Ignacy Ścibor Marchocki z Mińkowic, szlachcic podolski, w obliczu nadciągającej katastrofy spisuje projekt unicestwienia narodu, w myśl którego część obywateli podpali miasta, wsie i wszelkiego rodzaju zabudowania, a następnie $z$ dobytkiem wyruszy na pola i tam dokona zbiorowej samozagłady. Najpierw starzy i zniedołężniali, potem matki, żony, kochanki i niemowlęta złożą swe głowy na stosie ofiarnym.

Wówczas - powiada projektodawca - pozostałym a osieroconym rozpacz doda odwagi i albo zwyciężą albo zginą. Jeśli zginą, mogiła okrywająca szczątki zwyciężonych poszanowanie obudzać będzie w przechodniach i świecić przykładem następnym pokoleniom ${ }^{52}$.

Postulaty zamachu na zbiorowość, jak wynika z rozwinięcia wypowiedzi poetyckich, stanowią jedyną szansę znaku istnienia, dlatego $z$ taką determinacją są przez podmiot liryczny

\footnotetext{
${ }^{50}$ Z. Freud, Żaloba i melancholia, [w:] K. Pospiszyl, Zygmunt Freud. Cztowiek i dzieło, Wrocław 1991, s. 307. 51 "Jeszcze dotąd nadto bolem śmiertelnym ściśnione mam serce, abym tej okropnej pielgrzymki malował obraz. Nie widziałem w całej naturze, tylko grób ukochanej Ojczyzny, tylko mogiły usute dla walecznych i cnotliwych jej synów! Dla siebie sto razy śmierć wzywałem w pomoc, ale ta nie przyszła. Przepędzałem dzień i noc w milczeniu, noc w bezsenności..." - J. Wybicki, Życie moje oraz Wspomnienie o Andrzeju i Konstangji Zamoyskich, wyd. i obj. A. M. Skałkowski, Kraków 1927 (BN I 106), s. 208.

${ }_{52}$ Tu i ówdzie wspomina się, że autorami podobnego projektu po klęsce maciejowickiej byli gen. Józef Zajączek i Hugo Kolłątaj. Polacy mieli być postawieni w sytuacji bez wyjścia po patriotycznych rzeziach: królobójstwa, „wyrżnięcia” familii Stanisława Augusta oraz stronników i niewolników moskiewskich w liczbie 6000 . „A ponieważ takowa rzeź nie pozostawilaby nadziei pardonu, mieszkańcy więc byliby przymuszeni z ostateczną działać zapalczywością". (Cyt. za: M. Brandys, General Arbuz, Warszawa 1988, s. 44.)
} 
usprawiedliwiane. Dominuje w jego wywodach logika czystego aktu (,jestem, ponieważ domagam się zniszczenia"), a nie logika wyboru właściwej drogi, oparta na jakiś sensownych przesłankach, na przykład etycznych albo religijnych.

Pragnienie zagłady narodu swoje ostateczne rozstrzygnięcie znajduje w powątpiewaniu w opiekę Opatrzności oraz w przeświadczeniu, że naród ów nie sprostał wymaganiom Boga, dlatego został przez niego opuszczony i wydany na cierpienia:

Jeśli nas dłużej będą klęski biły,

Znać, że już nie dbasz o lud, niegdyś miły,

Strać nas od razu (...)

(J. P. Woronicz, Hymn do Boga w teraźniejszych okolicznościach kraju)

Depresja zakreśla jednak daleko rozleglejsze granice, wskutek czego postępujący proces interioryzacji doświadczonego absurdu dosięga w końcu istotowego centrum podmiotowości, przekraczając wszelkie okrywające go dotąd ograniczenia. Bezradność wobec narodowych nieszczęść i przerażenie infernalnym porządkiem świata implikują myśli samodestrukcyjne. Oznacza to, że życie znalazło się w stanie takiej nierównowagi, iż pozbawione zostało jakichkolwiek racji rozumowych. Podjęte zostają jeszcze co prawda irracjonalne próby jego zachowania w obszarze sensów i wartości, ale popęd ku śmierci poczyna przeważać, choć co prawda zostaje wysublimowany do sfery przeżyć patriotycznych. Powraca więc pragnienie śmierci w związku z upowszechnianym w okresie insurekcji kościuszkowskiej hasłem: śmierć albo niewola. Formułowane jest już jednak ono z innej niż wówczas perspektywy. U Kołłątaja w Elegii II wyrażone zostaje jeszcze w charakterystycznym narodowym kontekście: Obym się złączył z tymi, co dla swej Ojczyzny ponieśli śmierć ${ }^{53}$, z tym, że o śmierci mówi się tutaj już jako o straconej możliwości. Powtarza to pragnienie w innym miejscu, podkreślając zasięg zniewolenia, które przy utracie szansy śmierci postrzegane jest przez niego jako osobiście doświadczane przekleństwo losu:

Ja umrzeć chciałem, Tyran, co się na mnie srożył,

Żyć kazał, koniec tylko wolności położył ${ }^{54}$.

W Elegii I podobną myśl wypowiada podmiot zbiorowy, przerażony wieściami spod Maciejowic:

${ }^{53}$ Źródłem tego motywu, bardzo popularnego w literaturze porozbiorowej, była wg Cypriana Godebskiego

Eneida Wergiliusza, w której pojawia się charakterystyczny ustęp (I 94-96):

O trzykroć i czterykroć ci są szczęśliwszymi,

Co przed ojców obliczem na ojczystej ziemi

Znaleźli śmierć!

Cyt. za.: I. Chrzanowski, Optymizm i pesymizm polski. Studia z historii kultury, Warszawa 1971, s. 243.

${ }^{54}$ P. Żbikowski, Poezje więzienne Hugona Koltataja. Studia i teksty, Wrocław 1993, s. 159. 
Płacz powszechny w stolicy, na ulicach, rynkach, Po kościołach, pałacach, w ubogich budynkach, Jęk, co przerażał serca, sięgał aż do nieba, Ostrzegał jawnie, że nam umrzeć było trzeba ${ }^{55}$.

Swoisty syndrom presuicydalny organizuje warstwę ideową literatury porozbiorowej ze wszystkimi znaczącymi jego cechami, zawężającymi gwałtownie świat wartości i dewaluującymi wiele dziedzin życia. Bezimienny autor Myśli o ojczyźnie w apostrofie do śmierci umiłowanie ziemi dziadów i ojców ma za swoistą klątwę, tajemniczą a groźną siłę, od której nie można się uwolnić, ciążącą w postaci nader bolesnych uczuć i wspomnień:

Śmierci! wzywam twej pomocy.

Przyjdź, skończ moje wyrzekania.

Spokojny szukam skonania,

Uśpi mię snem wicznej nocy.

Tak gdy już raz legnę w grobie

Stojąc przed Boga obliczem,

Ojczyzno, gdy będę niczem,

Przestanę myśleć o tobie ${ }^{56}$.

Woronicz z kolei, powołując się w Świątyni Sybilli (pieśń IV) na przykład Katona Utyceńskiego, domaga się wręcz od Polaków, aby samobójczym gestem wyrazili swój sprzeciw i niezgodę na niesprawiedliwość, jakiej się dopuszczono na nich jako narodzie. Ukryty postulat takiej postawy znajdujemy w skardze i napomnieniu skierowanym pod adresem rodaków:

Królestwa Prozerpiny klucznico odźwierna!

Jużeś siadła na tronie $\mathrm{z}$ hebanu ciosanym.

Przygniótłszy świat uśpiony berłem ołowianym.

Zdrętwiało czucie w ponurej zaciszy,

Nikt mego obłąkania ni widzi, ni słyszy.

Prowadź mnie w twoim plaszczu do grobu Katona:

On nauczył, co czynić, gdy ojczyzna skona.

Czyliż na taką duszę Polaka nie stanie,

Jaką się wielkomyślni chlubili Rzymianie ${ }^{57}$

Bardziej rozpaczliwe i pokorne, a mniej wyrozumowane pragnienie zagłady osobistej pojawia się w Pieśni Rzewuskiego. Śmierć albo niewola nie są już tutaj możliwymi obiektami

\footnotetext{
55 Ibidem, s. 125.

${ }^{56}$ Myst o Ojczyźnie, rkps BUW 277: Wiersze różnych autoróu' z końca XVIII i poczq̨tku XIX uieku.

57 J. P. Woronicz, Pisma wybrane, op. cit., s. 200.
} 
świadomego wyboru człowieka, mogą być co najwyżej Bożą łaską lub jego karą, gdyż w warunkach narodowego upokorzenia Polak nie jest w stanie decydować o swoim losie:

Gdy święta Twa wola

Kajdan tych nie skruszy,

Niechaj życia dokonam.

Daj drugim rozkosze.

Ja o śmierć Cię proszę,

A Polakiem skonam ${ }^{58}$.

O śmierć prosi Boga zbiorowy podmiot Pieśni żotnierzy polskich ${ }^{59}$, o łódź Charona Ludwik Kropiński w wierszu Do czasu. Aleksander Linowski wspomina żałość ocalałych żołnierzy insurekcji, którzy stracili możliwość honorowej śmierci ${ }^{60}$. Były prezydent Warszawy, Ignacy Wyssogota Zakrzewski, zawiadomiony o zgonie swego przyjaciela Dębińskiego ze smutkiem wyznaje:

Winszuję mu szczęścia tego, iż na nieszczęścia ojczyzny naszej dalekim patrzy okiem i że onych doświadczeń zaprzestał ${ }^{61}$.

Wkrótce (w 1802 r.) i jemu to szczęście będzie dane.

Wprost o swoich samobójczych zamiarach w bluźnierczy sposób wypowiada się nieznany autor wiersza Stan nasz teraźniejszy. Forma utworu przypomina swoisty cyrograf, zawierany jednak nie $z$ szatanem, lecz z samym Bogiem. Przedmiotem usilnych zabiegów w nim wyrażonych jest przyzwolenie na odebranie sobie życia, a w dalszej kolejności prośba o wtrącenie do piekieł, jako że porządek infernum przedkładany jest przez zgnębionego Polaka nad hańbę życia w niewoli:

Kiedy dasz, Boże, koniec mej niedoli,

Racz niech przyspieszę śmierć skutkiem trucizny.

Najokrutniejsze furie piekielne

Do swoich jaskiń niech mnie wtrącą, wolę.

Niźli mam dłużej to zdzierstwo bezczelne

Znosić i cierpieć niesłuszną niewolę ${ }^{62}$.

Pojawiają się w poezji porozbiorowej pytania o sens życia czy nawet o prawo do życia po upadku państwa polskiego:

\footnotetext{
${ }^{58}$ Rkps Bibl. Czart. 2457 b IV, s. 109.

${ }^{59}$ Rkps BN BOZ 928, s. 274-275.

60 A. Linowski, List do Przyjaciela odkrywajacy uszystkie czynności Koltątaja u' ciagu insturekcji pisany $u$ r. 1795 , Wrocław 1864 , s. 3.

${ }^{61}$ Cyt. za: A. Zahorski, Ignacy Wyssogota Zakrzewski. Prezydent Warszany, Warszawa 1979, s. 281.

${ }^{62}$ Rkps Ossol. 327 II, k. 49.
} 
Gdy ci Polaka imię odjęte,

Czemu śmiesz jeszcze żyć, bracie? ${ }^{63}$

Te wątpliwości roznoszą Polacy po całej niemal Europie. Śmierć polityczna nie jest dla nich zmianą w życiu, lecz końcem wszystkiego. Na skalnych załomach Karlsbadu wśród wielu polskich wierszy znalazł się tekst, przypisywany w jednym z rękopisów zbioru Baworowskich Franciszkowi Ksaweremu Dmochowskiemu:

Polaku, za cóż pijesz wody wrzące,

Co je Wulkana moc czyni gorące?

Wszak twe podobne łzy do tego ścieku,

Pij więc łzy wlasne, dar smutnego wieku,

A w głębi skal tych kuj grobowiec sobie,

Nie masz Ojczyzny, cóż po życiu tobie? ${ }^{64}$

Jest coś rozpaczliwie agonalnego w tych wszystkich literackich zwierzeniach opisujących dramatyczne momenty szamotaniny życia ze śmiercią, gdy wszechobecność tej drugiej przeżywana jest świadomie i w bólu, bez psychicznej obrony, a przy takiej równocześnie udręce i połamaniu wewnętrznych barier, że z życia pozostaje jakieś oszołomienie irracjonalnym zamętem i przeczuciem zblizającej się osobistej katastrofy. Przypomina to chorobę, od której nie sposób się uwolnić i która nęka powracającymi napadami. Jej częstotliwość jest wskaźnikiem dezintegracji i załamania oraz zachwiania wewnętrznej organicznej równowagi, często w ówczesnej korespondencji i zapisach pamiętnikarskich utożsamianych z obłędem.

${ }^{63}$ S. Wodzicki, Nad mogitami szczekocińskimi, rkps Bibl. Jagiel. 7242, s. 40. Pragnienie śmierci pojawia się w wierszu Jędrzeja Świderskiego Dumania nad ojczyzną:

Nie masz cię dla mnie, Ojczyzno ma droga!

Ona mi życie słodziła;

Ach! pamięć twoja luba, razem sroga,

Bolem me serce zraniła!

Życie mi zmierzło... może koniec będzie...

Och, gdyby ciężar śmierć zdarzył!

Osierocony, stracony, w ohydzie,

Czemuż mnie z tobą nie zważył!

(Pieśni narodowe z różnych autorów polskich zebrane przez S. Bielskiego, Warszawa 1812, s. 51), a także w wierszu:

Ojciec i dzieci. Bajka po straconej ojczyźnie (1796), rkps, Ossol. 6265 I, k. 86:

Skąd ci przyszedł ten smutek, czegoś tak stroskany?

Raz dzieci rozkwilone ojca zapytały.

Równieś od naszej matki jak od nas kochany;

Masz przy tym do wygody majątek niemały.

$\mathrm{Na}$ co ojciec odpowie oblawszy się tzami:

Wolałbym was był nie znać, nieszczęśliwe dziatki;

Wolałbym razem w grobie zakopać się z wami

Niźli nas teraz widzieć bez powszechnej matki.

${ }^{6+}$ Rkps Bawor. 759, s. 29. Wiersz ten znajduje się również w rkpsie Ossol. 905 III, k. 157. 
Przekonanie o niemożliwości życia w zaistniałych warunkach w nich wyrażone nie wynika jednak z lęku czy cierpienia, które niezależnie od kontekstu dają się intelektualnie albo emocjonalnie wytłumaczyć i wprowadzić w wyższe struktury sensu, lecz jest następstwem uwarunkowań natury ontologicznej, istniejących w tym przypadku, jak ówcześnie sądzono, w swej formie ostatecznej, i nie dającej się zaakomodować do niczego. Z chwilą ostatniego rozbioru życie zostało jakby pokonane i unicestwione tak w wymiarze zbiorowym, jak jednostkowym. I choć nadal śmierć pozostaje poza obrębem afirmacji, a samobójca traktowany jest przede wszystkim jako sprawca zbrodni, a nie jej ofiara, to przewartościowania i tutaj są już zauważalne.

Zresztą w ogóle można mówić o swoistych tańcach i tryumfach śmierci na grobie Rzeczypospolitej, a przypomnijmy, że jej ofiarą padają pogrążeni w zgryzocie i „czarnej melancholii”, by wspomnieć pierwszych z brzegu, biskup smoleński, Adam Naruszewicz, starosta sobowiecki, dziwak i ekscentryk Szymon Kicki ${ }^{65}$, poeta i teoretyk literatury, Józef Szymanowski, autor podręczników szkolnych, ksiądz Grzegorz Piramowicz.

Fakt nasilenia się zgonów wśród pisarzy stanisławowskich w latach dziewięćdziesiątych XVIII wieku i pierwszych dziesięciu następnego stulecia potwierdzają badania statystyczne grup, środowisk i pokoleń oświeceniowych, przeprowadzone przez Elżbietę Aleksandrowską, których wyniki przedstawione zostały w haśle Pisarze - generacje $i$ rodowód spoteczny, zamieszczonym w Stowniku literatury polskiego oświecenia. Według zaprezentowanych tu zestawień szczyt wymieralności zaobserwować można wówczas zarówno wśród „inicjatorów” oświecenia (ur. w 1. 1710-1729, najwyższa liczba zgonów - 23 przypadki - w końcowym okresie Sejmu Wielkiego, targowicy, insurekcji kościuszkowskiej i rozbiorów), jak i jego „twórców” (ur. w 1. 1730-1749, najwyższą liczbę śmierci — 35 przypadków — osiągnęli w latach 1791, 1793-1799). „Działacze” (ur. 1750-1769) wymierają najintensywniej od 1805 roku. Te dane pozwalają badaczce sformułować wniosek o zależności nasilenia się zgonów od niekorzystnych wydarzeń politycznych u kresu Rzeczypospolitej:

Przedstawiając zjawisko w postaci wykresów uzyskalibyśmy dla pewnych lat historyczno-politycznie znaczących najwyższe wskaźniki („kominy”) zgonów, unaoczniające wybitną pomoc udzieloną przez historię biologii w jej rozrachunku z generacją. Rzecz przy tym znamienna, że na zwiększoną wymieralność pisarzy w tych latach wpłynęły bardziej nastroje psychiczne (zdenerwowanie, rozpacz, a nawet nadzieja) towarzyszące wydarzeniom niż bezpośrednie działania wojenne i represyjne, choć $\mathrm{i}$ ich udział był w procesie śmierci tych pokoleń znaczny ${ }^{66}$.

\footnotetext{
${ }^{65}$ Zob. N. Kicka, Pamiętniki, opr. T. Szafrański, Warszawa 1972, s. 75.

66 Slounik literatury polskiego oświecenia pod red. T. Kostkiewiczowej, Wrocław 1996, s. 402-403.
} 
Cudem wymyka się ze szponów śmierci pogrążony w rozstroju nerwowym ten, od którego „aż ziało cnotą”, Tadeusz Kościuszko. W niewoli moskiewskiej świadomie, niemal samobójczo, niszczy wnętrzności i osłabia organizm, ograniczając swój dzienny posiłek do kilku łyżek zupy. Badający Naczelnika lekarz donosi Woroncewowi, że „ustrój jego jest zupełnie zniszczony”, „nerwowa energia niepowetownie zniszczona” i raczej nie należy spodziewać się jego wyzdrowienia ${ }^{67}$. W tym samym czasie adiutant Kościuszki, Niemcewicz, w dzień i w nocy pilnowany jest przez sołdata, aby „co złego duszy swojej nie zrobił”.

Tak straszliwym otoczeni naokrom widokiem — pisze Stanisław Staszic — nie dozierając za sobą, tylko zwiększającą się coraz barziej grubą ciemność, przed sobą zgrozę zniszczenia, i tę, jeszcze okropniejszą, zgrozę czasu, w którym niszczeje i nadzieja... czarna rozpacz wtenczas osiadła duszę naszę ${ }^{68}$.

O swych skłonnościach samobójczych oraz „zabawnym” targnięciu się na własne życie wspomina przeor dominikanów wileńskich, ksiądz Ciecierski, oskarżony, a potem skazany za udział w spisku politycznym na utratę czci, szlachectwa i imion, majątku i godności, zesłanie na Sybir do ciężkich prac, „ocechowanie lica” oraz „wydarcie nozdrzów”. Postanowił mianowicie, nieprzywykły do alkoholu, otruć się "palącym, a jemu niezwyczajnym trunkiem”. Pomimo więc oporów wewnętrznych, raczy się pokaźną jego ilością:

Wzdrygałem się nieraz nad przedsięwzięciem mojem; religia bezbożność postępku wymiotła mi na oczy; po tysiąc razy odrzucałem zamiar i po tyle ż razy wracałem się do ulubionego przedsięwzięcia, mającego mi przynieść koniec początkowego nieszczęścia ${ }^{69}$.

Okazało się ostetecznie, że owym środkiem zbrodni nie była wódka, ale „dobry i przyjemny kwas".

Wspomniany Niemcewicz w więzieniu moskiewskim popada w tak wielka rozpacz, że raz obudziwszy się po dwugodzinnej drzemce odczuwał masochistyczną wręcz satysfakcję wypływającą z przeświadczenia o bezbolesnym zbliżeniu się w ciągu tych dwóch godzin do śmierci.

Władysław Wężyk uskarża się w pamiętnikach na swoją smutną starość, na osiwiały i martwy Witulin, na to, że jego synowie i córki, choć ich nie zaprzedał cudzoziemcom, rozdzieleni zostali zaborczymi granicami i pod przymusem włączono ich do obcych narodów.

Nam starym - dodaje - cośmy smutne chwile przeżyli na świecie, ale w pomyślniejszych na świat ten przyszli, teraz bardzo tęschno na sercu -

${ }^{67}$ Cyt. za: S. Askenazy, Przysiega Kó́ciuszki, „Biblioteka Warszawska” 1912, t. 1, s. 486.

${ }^{68}$ Wiek XIX. Sto lat mysli polskiej. Życiorysy, streszczenia, waqtki pod red. B. Chlebowskiego i in., t. 2, Warszawa 1907, s. 31.

${ }^{69}$ Pamiętnik księdza Ciecierskiego, przeora dominikanów wileńskich, Lwów 1865, s. 5. 
a gdyby nie ta myśl, że grób już blisko, to by człowiek nie wiedział już nawet, co tu poczynać na tym świecie! ${ }^{70}$

W szczególnie rozpaczliwej sytuacji znaleźli się oficerowie kościuszkowscy, pozbawieni jakichkolwiek środków do życia. Włóczyli się po kraju, kołacząc do drzwi pańskich w poszukiwaniu jakiegoś zajęcia i dachu nad głową. Nie wszystkim się to jednak udawało. Józef Drzewicki wspomina historię pewnego oficera artylerii, który szukał umyślnie śmierci w pojedynku, choć nie miał „do niego żadnej przyczyny”. Gdy później pytano go o powód „obrazy”, odpowiedział:

Obraza w moim losie, chciałem lepiej z jego [Drzewickiego - M. N.] ręki zginąć, niż później z głodu umierać ${ }^{71}$.

W tym przypadku przeświadczenie o wspólnym losie samobójców i zabitych w pojedynkach nabierało szczególnego wymiaru.

Popęd destrukcji i autodestrukcji w poezji porozbiorowej mial także swój wyraz w częstym sięganiu do skrajnych uczuć, a zwłaszcza rozpaczy ${ }^{72}$, przywoływanej wówczas nagminnie, pomimo że w oświeceniowej teorii poezji i retoryki, idąc śladem starożytności, zalecano, by odwoływać się do niej w wyjątkowych sytuacjach, usprawiedliwionych okolicznościami zewnętrznymi. Wówczas dopuszczalna była tylko i wyłącznie perswazja przeciw rozpaczy, stosowana w celu podtrzymywania na duchu odbiorców ${ }^{73}$. Tymczasem wbrew temu nakazowi w tekstach porozbiorowych, które zdołałem dotąd zgromadzić, słowo to pojawia się około czterdziestu razy w charakterystycznych dwóch ciągach asocjacji, obcych aksjologii okresu stanisławowskiego, którego etyka inkryminowała i opatrywala zwykle ujemnym znakiem wszelkiego rodzaju skrajne uczucia ${ }^{74}$. Jeden ciąg wyznacza tradycja poezji kościuszkowskiej. Tworzą go takie skojarzenia jak: odwaga i desperacja (Odpowiedź na deklaracje względem zaborów Polski), zemsta (Dumanie Polaka w zamku jazlowieckim), dzielność (Putawy - Pieśń III Niemcewicza), tułactwo (J. Świderski: Pieśn V), cnota (R. Korsak: Oda Jasińskie$m u$ ), męstwo i świętość (Do Juliana Niemcewicza). Drugi szereg skojarzeń jest jakby konsekwencją pierwszego i dotyczy bezpośrednio śmierci politycznej. Rozpacz jest tu wiązana z takimi kategoriami jak: sen (Na proskrypcje warszawskie), niesława i nieszczęście (B. Mało-

${ }^{70}$ W. Wężyk, Kronika rodzinna, opr. M. Dernałowicz, Warszawa 1987, s. 49.

7 J. Drzewicki, Pamiętniki (1772-1802), Wilno 1858, s. 61-62.

72 W przypisie do Barda Czartoryski zanotował:

Poemat ten napisany byl pod wrażeniem okropnej katastrofy 1794 roku — gdy przestrach i rozpacz były powszechne. Późniejsze klęski oswajały z nieszczęściem i utwierdzały nadzieję odrodzenia się — w roku 1794 w pierwszym przerażeniu zdawało się, że już żadnej nadziei nie było.

(Cyt. za: M. Janion, M. Żmigrodzka, Romantyzm i historia, Warszawa 1978, s. 59).

${ }^{73}$ Zob. M. Korolko, Sztuka retoryki. Przeuodnik encyklopedyczny, Warszawa 1990, s. 71.

${ }^{74} \mathrm{~S}$. Konarski uczył, że „i grzech jest wielki, i nigdy nie godzi się desperować o Rzeczypospolitej”, Krasicki z kolei w jednym ze swoich wierszy wołał: „Rozpacz — podział nikczemnych”. Pod hasłem Rozpacz w Uwagach pisał m.in.: „Rozpaczy w żadnym chwalebnym przymiotem sprząc nie można” (I. Krasicki: Uwagi, opr. Z. Libera, Warszawa 1997, s. 202). 
wieski: Wiersze...), hańba, kajdany i srogość losów (W. Turski: Na zamek krakowski), płacz, smutek, kara (Do Ojczyzny), trwoga i zbrodnia (Hymn zgnębionych Polaków). Zdecydowanie natomiast rzadziej pojawia się rozpacz we wspomnianych oświeceniowych kanonach wartościowania, zwykle jako życzenie albo wezwanie, aby się jej nie poddawać (L. Kropiński: Duma do ks. Adama Czartoryskiego, K. Koźmian: Do Ign. Potockiego, I. Krasicki Rozmowy zmarlych, tutaj rozmowa I między Solonem i Katonem Utyceńskim).

Według Piotra Żbikowskiego, w poezji porozbiorowej rozpacz pozbawiona została kwalifikatorów estetycznych i jawi się tutaj jako groźna siła destrukcyjna, która wyciska swoje niszczycielskie piętno na twarzy człowieka, rujnuje jego psychikę, przede wszystkim zaś rodzi zwątpienie w moralny porządek świata oraz w nieomylność i sprawiedliwość Bożej Opatrzności, niekiedy nawet w jej istnienie ${ }^{75}$.

Wojciech Bogusławski klasyfikując dla potrzeb teatru negatywne uczucia, rozpacz wymienia po żalu, niespokojności, zgryzocie, a przed utratą zmysłów. Definiuje ją w sposób następujący:

Boleść pochodząca z zupełnej utraty nadziei posiadania pożądanego dobra albo możności uniknienia okropnych wypadków ${ }^{76}$.

Podaje przy tym dwie jej odmiany: bierną, „dotkliwszą i bardziej udręczającą”, charakteryzującą się wyczerpaniem sił żywotnych, zaprzestaniem ekspansji w otaczający świat, introwertyzmem i bezsilnością, oraz druga, gwałtowną, „znośniejszą” od pierwszej, którą utożsamia $z$ desperacją, a egzemplifikuje ją zachowaniem wojownika rzucającego się w środek nieprzyjaciół, aby zginać lub „przebić się na wolność”. Towarzyszą więc tej odmianie rozpaczy równocześnie takie uczucia jak żal, przestrach i obłąkanie zmysłów, decydujące o ślepej odwadze rozpaczającego. Co ciekawe, jako jeden z przejawów rozpaczy gwałtownej wymienia Bogusławski skłonność do bluźnierstwa i złorzeczenia Bogu.

Podobnie ujmuje tę kategorię Ludwik Kropiński, rozpatrując rozpacz jako implikację pogłębiania się stanów smutku i żalu. Wskazuje jej skutki oraz zagrożenia, ze śmiercią włącznie, a także podkreśla patologiczny charakter rozpaczy:

Rozpacz wchodzi do serca po ustąpieniu z niego nadziei. Zajmuje całą duszę, wygania z niej tkliwość i rozczulenie, rozlewa jad swój zoółty na postać nieszczęśliwego i oczy, których wzrok przyjemny nasze podbijał serca, z których nieraz łza wypadła dla przyjaźni, litości i miłości, obłąkaniem i srogością przerażają nas dzisiaj i trwożą. Rozpacz ta nieszczęśliwa na całą naturę rozciąga czarną zasłonę, nie znosi blasku słońca, z pogardą depcze wonią i krasą uśmiechające się kwiaty, nienawidzi ludzi i samemu uwłacza Bogu. Okropność nocy, głos

\footnotetext{
${ }^{75}$ P. Żbikowski, Inspiracje religijne w poezji porozbiorowej (1793-1805) [w:] Motywy religijne $w$ twórczości pisarzy polskiego oświecenia, pod red. T. Kostkiewiczowej, Lublin 1995, s. 261.

${ }_{76}$ W. Bogusławski, Mimika, opr. J. Lipiński, T. Sievert, Warszawa 1965, s. 164-167.
} 
puszczyka, niezamieszkałe jaskinie, mogiły i głębokie milczenie są jej rozkoszami (...) Żal oswaja człowieka z cierpieniem, hartuje uczucia i osłabia chęć do życia. Rozpacz nieszczęśliwych wprowadza do grobu ${ }^{77}$.

Nie inaczej rzecz przedstawia autor wiersza Rozpacz, w którym uczucie to analizowane jest w oparciu o szereg przeciwieństw konstruowanych na dychotomii Życia i Śmierci. Pragnienie tej drugiej, przy „głuchocie nieba” przybiera postać rojeń samobójczych:

Dość tych nieszczęść — już więcej człek ich znieść nie zdoła, Śmierć, śmierć wszystko niech kończy, przyrodzenie woła.

Gdzież śmierci szukać będę? - i ta się już kryje, Wszystko dla mnie nieszczęściem, wszystko dla mnie żyje.

Umrzeć chcę, żyć nie mogę - w tej smutnej kolei

Nie masz potrzeby życia, gdzie nie masz nadziei.

Bogowie! was ród ludzki za dar życia chwali, Ja was proszę, byście go nazad odebrali.

Głuche niebo, nie słyszy tych jęków — więc tedy

Ja bogiem moim będę, zrobię kres mej biedy.

Ręko! nikczemna ręko, której dotąd siła

Ledwie mi pierwszych potrzeb życia dostarczyła.

Tego mi męstwa trzeba, weź to krwie narzędzie,

Jedno jego użycie zgonem moim będzie.

$\mathrm{Nie}$, nie boli ta rana, którą wyrwę duszę.

Obrońcą moim jestem, gdy katem być muszę.

Umieram - już śmiertelną ćmą się oczy marą,

Śmierć dla mnie dziś jest łaską, złym niech będzie karą ${ }^{78}$.

Nurzanie się w śmierci i zapowiadających ją skrajnych uczuciach, różnego rodzaju formy złorzeczenia Bogu, przypadki patologii i dziwactw czy wreszcie oziębłość religijna musiały być zjawiskami stosunkowo częstymi w tym czasie, skoro powołuje się na nie Hieronim Juszyński w kazaniu jubileuszowym wygłoszonym w kościele katedralnym w Tarnowie 1 VI 1795 r. W pierwszej części, mającej charakter egzorcyzmów, kaznodzieja prosi Boga o to, aby okazał łaskę ,językowi szalonej rozpaczy”, oskarżającemu go o niesprawiedliwość i zapomnienie zasług. Wspomina z żalem „poczciwych obywatelów”, którzy pozostawieni „dzikiemu losowi”, bez ojczyzny, przeklinali dzień urodzenia i złorzeczyli swojemu życiu.

Zjawiska powyższe decydowały o duchowości czasów porozbiorowych. Znawca problematyki, Karol Górski, uważa, że okres od 1795 do 1830 r. charakteryzuje się najgłębszym w naszej historii upadkiem religijności w ogóle, a życia wewnętrznego w szczególności.

77 L. Kropiński, Żal, smutek, rozpacz, rkps Bibl. Czart. 3070 II, s. 125-126.

78 Rkps Ossol. 1084 III: Pisma J. Sygierta, k. 39. W rkpsie Bawor. 759, s. 92-93 wiersz ten został przypisany księdzu Łańcuckiemu. 
Dotyczy to także według niego praktyk religijnych, łamania postów, częstych rozwodów, odwlekania latami chrztu dzieci, nasilania się przypadków przechodzenia z katolicyzmu na protestantyzm $^{79}$.

Ta sytuacja oczywiście miała swoje ideowe podłoże, albowiem odejścia od normy i patologie, zasygnalizowane poprzednio, wynikały przede wszystkim z historycznych uwarunkowań. Pierwsze ich oznaki pojawiały się w momencie zanegowania wraz z upadkiem państwa wartości klasycznych, takich jak ład, sprawiedliwość, porządek oraz zachwiania związanej z nimi wiary w sprawiedliwe wyroki Opatrzności. O jej drogach, jak dowiadujemy się z pamiętników, zwątpił Adam J. Czartoryski, co potwierdził także literacką kreacją swoich bohaterów, starca samobójcy i obłąkanej dziewczyny. Dziewica, rozpaczająca po utracie ojczyzny, rodziców i narzeczonego, oskarża wprost Boga o to, że stanął po stronie niesprawiedliwej przemocy, wysłuchał „krwawożerców prośby” i „ziścił srogie układy”, a pozostał nieczuły na błagania i łzy ciemiężonego narodu. Skargom Starca sędziwość i zbliżanie się do kresu ziemskiej wędrówki nadają szczególne piętno:

$\mathrm{Na}$ toż lat tyle pobożnie przeżyłem, Być w końcu życia, o potworo sroga [Katarzyna II]

Przyczyną była, że nawet zwątpiłem

O rządzie prawej Opatrzności Boga? ${ }^{80}$

Nawet u Woronicza pojawia się w Hymnie do Boga ukryte echo powątpiewania włożone w usta przechodnia:

Pamięć naszą uczciwą, głośną wpoprzek świata, Jak skorupę garncarską, o kamień stłuczoną, Pogwizdując wędrowiec depce i pomiata, A patrząc na bram naszych postać okopconą, Potrząsa głową i pyta zdumiony: „I gdzież ich teraz ów Bóg zawołany?... 81

${ }^{79}$ K. Górski, Zarys dziejów duchowości w Polsce, Kraków 1986, s. 267. Zob. też s. 276-278. Wcześniej podobne wnioski formułował Eustachy Iwanowski:

Obojętność religijna od czasu rozbioru kraju nieskończenie się powiększyła i w Księstwie Warszawskim wyjawiła się zupełnie. Obojętność ta, cynizm, do ludu nie doszły, ale w klasie cywilizowanej bardzo się rozwinęła. Niedowiarkami bezbożnymi byli wszyscy literaci, urzędnicy, posłowie i niemal wszystkie salony (...) Ojczyzna! Polska! były hasłem tej epoki. Bóg, Kościól, święta wiara utraciył siłę swoją i znaczenie. Nie zapalała serc, nie unosiła do poświęceń miłość Boga i Kościoła. Nie postawiono na tym fundamencie miłości Ojczyzny.

(E. Iwanowski) Helleniusz, Wspomnienia lat minionych, Kraków 1876, s. 45-46.

${ }_{80}$ A. J. Czartoryski, Bard polski 1795, wyd. i wst. J. Kallenbach, Brody [1912] (w. 495-499).

${ }^{81}$ Skorygować dzisiaj możemy opinię Władysława Włocha, jakoby złorzeczenia czy wątpliwości kierowane pod adresem Boga w Bardzie polskim były odosobnioną nowością. Wydawca wierszy porozbiorowych pisze m.in.: 
W liście z 30 września 1802 roku do swojej matki Adam Jerzy pisze, że życie wydaje mu się ciężarem nie do udźwignięcia i tylko jakiś wewnętrzny przymus pozwala mu stawić czoło jego okrutnym wymaganiom. Podkreśla po raz kolejny, że żyje tylko teraźniejszością, nie mając ani planów na przyszłość, ani celu, który by go osobiście dotyczył ${ }^{82}$.

Podobne tony niejednoznacznego określenia się wobec wyroków boskich znajdujemy w innych utworach z tego okresu. U Kniaźnina w wierszu Do Muzy mojej, u Staszica w Rodzie ludzkim:

Dla zachowań jestestwa wielkiego narodu

Głuchym, nieczułym wszystko, aż do bogów było!... ${ }^{83}$

W bezimiennym wierszu Mysl o ojczyźnie:

Wszystko doli naszej wrogiem,

Bóg nam nie chce być nadzieją,

Klęski duszą naszą chwieją ${ }^{84}$.

U Morelowskiego w Śnie:

Kiedyż złamał Ci Polak albo ludziom wiarę?

Niech kto będzie winniejszy, ten odniesie karę ${ }^{85}$.

Jezuita połocki przy wskazaniu na pewne zaniedbania i występki Polaków poczytuje naród polski za niewinny w porównaniu z zaborczymi państwami. Skwapliwie przypomina więc zbrodnie wrogów tak ciężkie, iż Polska ze swymi wykroczeniami istotnie wydaje się być nieskażoną. Wobec tego kara, która ją spotkała, jest aktem niesprawiedliwości dziejowej. Podmiot usilnie poszukuje tych argumentów, które broniłyby jego własnej oceny historycznej. Jest gotów nawet jak niegdyś Mojżesz przed zagładą Sodomy i Gomory prowadzić z Bogiem spór o niewinnych:

Wspomnij, Ojcze niewinnych, na złe wrogów czyny

Sądź mię i z nimi ukarz, kto $z$ nas będzie winny.

(Sen, ww. 124-125).

Jedno wszakże uczucie, wypowiedziane w Bardzie polskim, jest w elegii patriotycznej epoki rozbiorów nowością: żal do Boga, bunt przeciwko Bogu; Kniaźnin biadał, że „wyuzdała się złość sroga, jakby już nie było Boga", ale nie podawał bynajmniej w wątpliwość sprawiedliwości bożej, wierząc mocno, że prędzej czy później, Bóg „ukaże światu w swym cudzie, że Jego ziemia i ludzie”. Inaczej być nie mogło: miano przecie świadomość popełnionych win, więc nieszczęścia narodowe poczytywano za sprawiedliwą karę. W Bardzie polskim tymczasem dźwięczy przekonanie, że Polska jest niewinna, że więc cierpi niesłusznie (...).

(W. Whoch, Polska elegia patriotyczna w epoce rozbiorów, Kraków 1916, s. 43).

${ }^{82}$ M. Handelsman, Adam Czartoryski, t. 1, Warszawa 1948, s. 41.

${ }^{83}$ S. Staszic, Ród ludzki. Poema dydaktyczne, opr. Z. Daszkowski, przedm. B. Suchodolski, Warszawa 1959.

${ }^{84}$ Rkps BUW 277: Wiersze różnych autorów z końca XVIII i początku XIX wieku, s. 136.

${ }^{85}$ Wiersze Józefa Morelowskiego, op. cit., s. 49. 
Podobne żale do Boga kieruje w swoich pamiętnikach Eustachy Sanguszko:

W roku tymże 1795 ostatni podział stanowi smutną epokę. Tak gdy groźne niebo wziąwszy dąb potężny za cel gniewu swego, piorun po piorunie w niego waląc, poślednim razem i pień kruszy, tak i ostatni podział 1795 roku rdzeń już Ojczyzny naszej szarpiąc, Polskę z kart narodów ściera. Lecz sposób, o Boże, w którym nas dotykasz, nie jestże najsroższym? Niech w walce dwóch tęgich braci ręka Twoja ciążąc na wiernym Ci Lechu, pobłaża ślepemu Russa szczęściu. Ależ czemuż niełaska Twoja trapi nas jeszcze i pokoleniem synów Rudolfa? ${ }^{86}$

W Trenach upadku Polski nieznany autor wyraża przekonanie, że Bóg nie interesuje się losami i cierpieniami ludzi, ponieważ jest bezsilny wobec zła czynionego przez tyranów. O „czczych modłach” pisze Wincenty Turski (Na zamek krakowski, którego osobliwości ogląala księżna Sanguszkowa z córkami swoimi r. 1795). Pojawiają się paradoksalne modlitwy do Boga, aby uchronił nieszczęśliwych Polaków przed bluźnierstwami wobec niego:

Stwórco, coś zdziałał słońce, ziemię, morze,

W najmniejszym Twoim dziele, nader wielki Boże,

Ukróć chwile niewoli, ukróć hańby miary,

Zważ nasze przewrotności i zważ przeciąg kary.

A gdy jeszcze Twa słuszność chce nas mieć na probie,

Dodawaj męstwa, byśmy nie bluźnili Tobie ${ }^{87}$.

Towarzyszą temu wątpliwości co do nieomylności Bożej i słuszności jego wyroków:

Boże! czyli co tworzysz, czyli co wywracasz,

Dotąd jak sprawiedliwe dzieła Twoje słyną.

Niknie Kartago! Wolny Rzym wielki wytracasz,

Rzym upada, lecz podłe tyrany w nim giną.

Polska ginie - mogła tak zemstą twą zasłużyć,

Lecz czy trzeba jej zgubą Katarzynie służyć? ${ }^{88}$

W ten sposób zło wyrządzone Polsce i powszechne cierpienie przez nie sprowadzone stawia twórców wierszy porozbiorowych nie tylko w obliczu zwątpienia w sprawiedliwe rządy Opatrzności nad światem, ale również przed dręczącym i niebezpiecznym obrazem „Złego boga”. Niebezpiecznym, gdyż zagrażającym oświeceniowej wizji świata, do której nie dopuszczano ani przypadku, ani zła niezawinionego, ani cierpienia pozbawionego transcendencji, ani tym bardziej zniewolonych czy nierozumnych działań człowieka.

${ }^{86}$ E. Sanguszko, Parmiętnik 1786-1815, wyd. J. Szujski, Kraków 1876, s. 48.

${ }^{87}$ Do Kościuszki, rkps Ossol. 692 I, k. 34.

${ }^{88}$ Do Ojczyzny, rkps Ossol. 692 I, k. 64. 
U Hugona Kolłątaja w Hymnie I wątpliwości zebrane zostały w pytania, co sugerować ma zagubienie intelektualne podmiotu lirycznego. Zapytuje ksiądz podkanclerzy o odwrócone oblicze Boga, o to, czy stoi on przy „sprawie niewinności” i kiedy sprawiedliwie odplaci bezbożnym. Wyraża wreszcie wątpliwości co do Jego Opatrznościowego udziału w sprawach ludzkich, albowiem nie potrafi zrozumieć szczęścia „złośliwych” i „łez” pokornych. Co więcej, skargi „zawieszone” w pytaniach wyzwalają w nim, tak jak później w mickiewiczowskim Konradzie, odruch zniecierpliwienia, nacechowany rozgoryczeniem i wewnętrzną niezgodą na porządek moralny świata. W tym przypadku znika jednakże perspektywa spraw zbiorowych, obecna w poprzednich skargach. Podmiot zapominając się w swym żalu już nie mówi w imieniu milionów pokrzywdzonych i nieszczęśliwych, lecz w swoim własnym:

Czemuż mię opuściłeś, Boże sprawiedliwy?

Spojrzyj, jak utrapienia wyższe nad me błędy,

Uciskają bez ulgi byt mój nieszczęśliwy!

Znikąd pomocy, zemsta czuwa na mnie wszędy! 89

Owe, najprawdopodobniej częste wówczas, jak sądzi Wacław Berent ${ }^{90}$, odczucia Józef Wybicki w gorzkiej historycznej retrospekcji wypowiedzianej w Płocku 29 grudnia 1806 roku uogólnia do postaci konkluzji:

(...) z wolności chlubnej w służebniczą ujęci niewolę, obciążeni więzy, okryci pogardą, obcym potępiani językiem, złupieni z majątków, odarci z ojców naszych sławy, w groby śmierci lub milczenia wtrąceni, nie widzieliśmy już na ziemi dla siebie obrony, a zrozpaczeni o pomocy niebios traciliśmy nadzieję mieć pociechę z góry ${ }^{91}$.

Łagodzone jest nieco ostrze bezpośrednich oskarżeń Boga o niezasłużoną krzywdę i wielką dziejową niesprawiedliwość przywoływaną raz po raz kategorią Losu. Jest ona jakby najwyższą instancją i ostateczną wobec dziejów, a przy tym wyzbytą z nacechowań aksjologicznych, takich jak: dobro-zło, niesprawiedliwość-sprawiedliwość, nagroda-kara, cnota-występek.

${ }^{89}$ P. Żbikowski, Poezje więzienne Hugona Kottataja..., op. cit., s. 145.

${ }^{90}$ Sytuację religijną w momencie upadku państwa autor Nurtu ocenia następująco:

Po największych nawet klęskach średniowiecza - wojny, moru i spustoszeń - nie nastawał równie gwałtowny wstrząs psychiki gromadnej. Nagminna zaraza melancholii czarnej, której ofiarą padło aż trzech najwybitniejszych poetów narodu - tego nigdzie nie było! „zmożona rozpacz, bierna, rozbrojona” zapadła w chaos. Co dziwniejsze, że nie szukała zrazu, jak wszędzie i zawsze po kataklizmach wielkich, ratunku w wierze. Przepełnione w chwilach trwogi, po wkroczeniu najeźdźców opustoszały kościoły. „Żółć uciśniona" zwracała się buntem przeciw Opatrzności, a kończyła się na zaciętej niewierze w jej rządy nad światem: przemożniejsze moce gwaltu, zdrady i zbrodni kierują losem narodów. „Wszystko już zginęło!”, a ratunek każdemu ,już w zgonie, nie w życiu".

(W. Berent, Nurt. Opowieści biograficzne, Warszawa 1934, s. 117).

${ }_{91}$ Archiwum Wybickiego, opr. A. M. Skałkowski, t. 1, Gdańsk 1948, s. 79. Z drugiej jednak strony podkreśla Wybicki w swoich pamiętnikach, że pociecha religijna, bezgraniczne poddanie się woli nieba, pozwoliło mu znosić nieszczęścia, oraz oddzielać cierpienia duszy od popadania w rozpacz. 
Uwalnia więc częściowo Boga od odpowiedzialności za zachwianą równowagę porządku świata i historii. Ale, jak podkreśla Piotr Żbikowski, równocześnie w sposób wręcz świętokradczy deformuje istotę Opatrzności i prawdziwy charakter jej władzy nad światem ${ }^{92}$. Los w tego typu konkretyzacjach jako hipostaza Stwórcy jest pośrednią formą zwątpienia w jego sprawiedliwość oraz miłosierdzie. Służy kamuflażowi profanacji. Podobną funkcję spełnia Czas, w chwili upadku państwa nabierający silnych znamion i obciążeń egzystencjalnych ${ }^{93}$.

\section{Tworzenie nowych relacji (reintegracja)}

Dodać należy, że wszystkie wspomniane powyżej wątpliwości formułowane byly z perspektywy religijnej, w modlitwach, apostrofach do Boga, często z świadomością bluźnierstwa, dlatego nie można ich w pełni uznać za dowód załamania wiary w ogóle, podobnie jak nie wyraża tego ani Tren XI Kochanowskiego, ani Improwizacja Mickiewicza. Tego typu „zachwiania” i „rozluźnienia” ufności religijnej mają miejsce w sytuacji komunikacyjnej, w której dystans między człowiekiem a Bogiem zostaje zmniejszony pytaniami i wątpliwościami o randze najwyższej tego ostatniego. „Bluźnierstwa” owe sugerują w zasadzie postawę pytająca, w której oczekiwanie jest wyrazem zagubienia, braku orientacji, przytłoczenia faktami, a nie wyrazem utraty wiary. Zmniejszenie dystansu i postawa roszczeniowa niekoniecznie onaczają więc oddalanie się od Boga, raczej przeciwnie, w krańcowej rozpaczy człowiek liczy już tylko na jego miłosierdzie, przejawiające się przede wszystkim w rozwiązaniach intelektualnych, wyjaśnieniach, podpowiedziach, sugestiach porządku, wskazaniach celu i sensu. Jakkolwiek bezlitosne są odmowy i sprzeciwy czlowieka, to jednak nie niszczy on całkowicie przedmiotów swej tęsknoty, nawet w najbardziej tragicznych dla siebie i skrajnie niekorzystnych sytuacjach. Rzecz w tym, że dąży on do owej bliskości poprzez powątpiewanie, podważenie myślowego porządku, jakby spodziewając się, że Bóg zawęży metafizyczny obszar tajemnicy, uchyli rąbka wiedzy o swoich planach, skoryguje błędne wnioskowanie, wytłumaczy katastrofę, cierpienie, śmierć, obłęd. Wątpliwości, w których mnożą się „może”, „czyż”, ,jakby” w odniesieniu do Boga, wyrażają postawę nie zerwania, odwrócenia się, ale poszukiwania i oczekiwania, i s̨a najłatwiejszą drogą do religijnej gorliwości i bezgranicznego zaufania. Częściowo (ale tylko częściowo) rację ma więc Ludwik Dębicki piszący pod koniec ubiegłego wieku:

Z upadkiem bytu Rzeczypospolitej polityczne ustają wiersze, zaczyna się elegia patriotyczna i przechodzi w mistyczne tony lub pieśn obozową, powstańczą. Wiersze tego drugiego okresu zrywają pakt, jaki istniał między poezją a filozofią XVIII wieku (...) Niezwykły to objaw w dziejach literatury, tak nagte przejście i taki

${ }^{92}$ P. Żbikowski, Inspiracje religijne w poezji porozbiorowej (1793-1805)..., op. cit., s. 255-256.

${ }_{93}$ Wymiennie też wykorzystuje się do tych celów kategorie: „Wyrok”, „Niebo”, „bogi”. 
zwrot po realizmie do idealizmu, z sceptycyzmu i niedowiarstwa do prostej i gorącej religijności, z wyuzdania i rozpasania w czyste, duchowe sfery ${ }^{94}$.

Wszelkich niedowiarków wzywał do poprawy Ludwik Osiński w wierszu Bóg, w którym wyjaśniał Opatrznościowy porządek świata oraz uwarunkowania wzrostu i upadku narodów, powtarzając równocześnie popularne w tym czasie przeświadczenie o słabości i ograniczoności ludzkego rozumu, o niemożliwości przeniknięcia przezeń zasłony pokrywającej zagadki bytu. Ostatecznym dowodem na istnienie Boga nie jest jednak dla Osińskiego natura czy posłannictwo narodów, lecz człowiek w swej wyjątkowości i niepowtarzalności:

Zuchwały mędrku! jeśli jesteś kędy,

Ty co śmiesz bożej zaprzeczać potędze,

Padnij - a harde mdłych docieczeń błędy

Skrusz - i moc Bóstwa uznaj w świata księdze.

Jest Bóg — boś ty jest - jest wszędy przytomny,

Wszechmocny, mądry, sprawiedliwy, wieczny.

Opiewa bytność Jego świat ogromny

I łańcuch przyczyn i skutków koniecznych ${ }^{95}$.

Wątpiący usiłują więc ostatecznie w starych strukturach sensu i znaczeń szukać takich rozstrzygnięć, które przy akceptacji prowidencjalnej wizji dziejów uwzględniłyby sens historycznego zła i cierpienia. Przez nadanie wyższego sensu przenoszonym w dziejach nieszczęściom dokonywana jest ich racjonalizacja i waloryzacja, tak że ze stanu negatywnego przeistaczają się w doświadczenia o pozytywnej treści duchowej. Rozwiązań stąd wynikłych pojawiło się kilka, od moralnego oczyszczenia i wypróbowania wierności począwszy, a na aktualizacji idei mesjanizmu skończywszy. Znane są powszechnie koncepcje i spekulacje religijne Morelowskiego, Kołłątaja, Kniaźnina i Woronicza. Wspomnieć jeszcze należy Feliksa Bentkowskiego udowadniającego ponad wszelką wątpliwość, że w planach Opatrzności częstokroć to „co niemożliwym się zdaje, z czasem zbawienne się okazuje" 96 , oraz Józefa Szaniawskiego, skłaniającego się ku represyjnemu interpretowaniu katastrofy państwa:

Żaden lud, po zbyt długich ku zupełnemu zepsuciu postępach, nie mógł stanąć na drodze prawdziwego odrodzenia, jak tylko przechodząc przez srogie klęski i straty: Polacy musieli przez samą śmierć polityczną przechodzić do istotniejszego życia. Sam jedynie zgonu widok mógł prawdziwą cenę czerstwego bytu dać uczuć narodowi, który się tak dalece zapomniał w długim obłąkaniu; tak chciała ratująca Opatrzność, a tu wywód trafny dróg, przez które ona nas

94 L. Dębicki, Franciszek Dionizy Kniaźnin, „Przewodnik Naukowy i Literacki” 1888, t. 16, z. 9, s. 845.

95 L. Osiński, Zbiór zabawek wierszem, Warszawa 1799, s. 6.

96 Zob. A. F. Grabski, Mysl historyczna polskiego Oświecenia, Warszawa 1976, s. 265. 
przeprowadza, mógłby pod piórem głębszego badacza zostać osnową najobfitszego w nauczne przestrogi dzieła politycznej Teodycei naszej; takowych przerażających ostateczności środków potrzeba było dla zupełnego uleczenia ${ }^{97}$.

Julian Ursyn Niemcewicz pocieszał siebie i innych tym, że być może „cios okropny, który w cieniach śmierci przez lat tyle naród polski pogrążył” z czasem okaże się „dobroczynnym Opatrzności zrządzeniem" ${ }^{98}$. Tę konsolację osadzał na przekonaniu, że wszystko w świecie ma swoją logikę, cel i wyznaczone miejsce, wszystko „wszechmocna Istność napełnia swoim duchem”, który decyduje nie tyle o szczegółach, co o „ogólnych ustawach” i całokształcie. Zbrodnia polityczna czy zbrodniarz w planach dziejów jest tylko środkiem, odmianą czy raczej jedną z wielu możliwych wersji konieczności:

Niech się więc tkliwość nasza w żalach swych uśmierza,

Złe oddzielne do dobra powszechnego zmierza (...)

Jeźli świat ten wstrząsają żywiołów niezgody,

Rozjuszony Tamerlan pustoszy narody,

Kto wie nie znanym końcem, jeźli rządca świata,

Ten, co podnosi morze i na wiatrach lata,

Nie wlal zbrodniczej pychy w serce Katyliny

I nie zesłał morderczej na świat Katarzyny.

Nie zdolni Twórcy wielkich zamiarów postrzegać,

Z zniżonym w ziemię czołem umiejmy podlegać 99 .

Metafizyka tego rodzaju, by posłużyć się opinią Maxa Schelera, konstruowała do każdego szeregu i przejawu zła w rzeczywistości historycznej niewidzialny porządek realności, w którym jedynie „pozorne” zło przestaje być złem i staje się dobrem, jako że ostatecznie prowadzi do utrwalenia tożsamości czy szerzej rzecz biorąc do zbawienia, decyduje o rozwoju moralnym i religijnym, przybliżając do Boga ${ }^{100}$.

Już jednak i tutaj dają się zauważyć elementy fatalistycznego myślenia o historii, której człowiek i narody nie są w stanie podporządkować sobie wedle własnych pragnień i celów, choćby najchlubniejszych. Doprowadzi to stanowisko do charakterystycznych przewartościowań w obrębie optymistycznej epistemologii oświecenia. Sprawiedliwość, miłosierdzie, posłannictwo wyparte zostaną przez zintelektualizowaną kategorię konieczności:

Czymże są ludzkie układy, zamiary, zabiegi? Opatrzność, która jedyna zarządza światem, naigrywa się z nich, ludzie są tylko jej narzędziem do spełniania jej

\footnotetext{
${ }^{97}$ J. K. Szaniawski, Pochwała Cypriana Godebskiego, „Roczniki Towarzystwa Królewskiego Warszawskiego Przyjaciół Nauk”, t. VIII, Warszawa 1809, cyt. za: I. Chrzanowski, Optymizm i pesymizm polski ..., op. cit., s. 175. 98 J. U. Niemcewicz, Śpiewy historyczne, Kraków 1935, s. 436.

99 J. U. Niemcewicz, Cztery pory życia lidzkiego, wyd. M. Brzezina, „Archiwum Literackie”, t. 18: Miscellanea $z$ doby Ośúiecenia 4, Wrocław 1973, s. 459.

${ }_{100}$ M. Scheler, Cierpienie, śmierć, dalsze życie, tł. i opr. A. Węgrzycki, Warszawa 1994, s. 52.
} 
odwiecznych wyroków, które raz wybiera, drugi raz kruszy, aby poznali swoją nicośćc1.

Powtarza Koźmian swoje przemyślenia na temat związków Boga i człowieka poprzez historię w Modlitwie o pokój, wskazując na to, że błagania ludzkie są daremne, ponieważ Bóg w porządku świata wyznaczył cele i środki, których nie może naruszyć czy wręcz nie jest w stanie tego uczynić. Dlatego pozostaje nieczuły na wszelkiego rodzaju przejawy cierpienia i niesprawiedliwości, mając na uwadze ogólny plan historii i jej znaczenie w planie zbawienia. Tak nieludzka koncepcja Stwórcy zostaje jednak w końcowych wersach wiersza przeformułowana. Autor Ziemiaństu'a ostatecznie przyznaje się do swego błądzenia wywołanego rozpaczą i w zakończeniu wiersza daleki jest od tego, aby myśleć, że sprawiedliwy człowiek pozostaje bez boskiej opieki. Stąd wyrok, według niego, jest kwestią czasu.

Hugo Kołłątaj w Smutku II z 3 czerwca 1796 roku pokornie i „bez szemrania” poddaje się cały boskim ustanowieniom, zapewniając, że los zesłany przez Boga zniesie w cierpliwości. Spekulacje teoriopoznawcze wywołane własnymi cierpieniami i nieszczęściami kraju prowadzą go więc w końcu do całkowitego zawierzenia Stwórcy i ufności w jego sprawiedliwość. Nie jest to, jak podkreśla Piotr Żbikowski ${ }^{102}$, „wyrozumowany” fideizm, ale religijność zrodzona z potrzeby serca, powtarzająca katechizmowe zasady wiary, sprowadzające przeznaczenie człowieka do eschatologii i kresu historii:

101 K. Koźmian, Pamiętniki,op. cit., t. 2, s. 59.

Podobne rozważania w Rozbiorze krytycznym (1795-1802) czyni Hugo Kołłątaj, zaznaczając, że nie zawsze to co nas zadziwia lub przestrasza, a czego przyczyn i celu określić nie potrafimy, jest przypadkowe i "osobliwe", albowiem może mieć swoje uzasadnienie w „przyrodzeniu” i wyższym porządku rzeczy, nad którym czuwa Bóg. Cokolwiek więc dzieje się na świecie, zsotało dopuszczone wolą Najwyższego, który „sprzeczne nawet podług naszego pojęcia wypadki” odnosi do wyznaczonej przez siebie konieczności i „całości tej niezmiernej budowy oraz jej celów".

Intelektualistyczną koncepcję Boga dziejów prezentuje Stanisław Staszic w Rodzie ludzkim. Wyklucza on możliwość jakiegokolwiek uprzywilejowania, narodowego czy jednostkowego, podporządkowując wszystko i wszystkich niezmiennym prawom i raz na zawsze ustanowionym wyrokom:

Do tych praw odwiecznego z nami związków Jestwa

Wszystko się ma stosować lub istność utracać,

Podług nich jedne światy tworzą się i krążą,

Drugie się roztwarzają, w żywioł zwracać muszą;

Podług nich przy każdym naokoło z światów

Iszczą się w parokręgach z pierwotnych żywiołów

Wszystkie stosunki (...)

Bóg jest wedlug Staszica koniecznością praw rządzących światem, nieprzeniknioną i niepoznawalną ludzkim rozumem, stąd także zakryte są przed czlowiekiem wszelkie nadrzędne sensy historyczne:

Tyś Jestwo! na którego niepojętość patrzę,

Lecz którego początku, końca nie pojmuję;

Twą moc wszędzie, ustawnie nad sobą doznawam,

Lecz sobie wyobrazić nigdy Cię nie zdołam.

(S. Staszic: Ród ludzki, księga XVIII, t. IX, cyt. za: Wiek XIX. Sto lat mysti polskiej..., op. cit., s. 42).

102 P. Zbikowski, „... Serce poddane opatrzności uyrokom...” Bóg i religia u spuściźnie literackiej Hugona Koltąaja, „Zeszyty Naukowe Wyższej Szkoły Pedagogicznej w Rzeszowie”. Seria filologiczna, z. 13/1994, s. 59. 
Ufam Twej Opatrzności, znam Cię stała wiarą, Choćbyśs o mnie zapomniał wśród tylu przykrości.

Tajemnice dziejów i porządku świata, o których ujawnienie dopominał się, uznaje ostatecznie Kołłątaj za czynniki konstytuujące transcendencję. Nie mogą być one w żaden sposób poznane przez człowieka, ponieważ nie jest on w stanie przybliżyć się do ostatecznej prawdy o motywach i przyczynach wyroków Opatrzności.

Ambiwalencję uczuć związanych z jednej strony z negatywnymi stanami psychicznymi po upadku państwa, $z$ drugiej $z$ wysiłkami intelektualno-wolicjonalnymi na rzecz przyzwyczajenia się do nowej sytuacji i próbą znalezienia w niej dla siebie odpowiedniego miejsca, znajdujemy w przemyconym z więzienia liście Kołłątaja do Kościuszki, w którym nadawca kreśli rozległe plany prac historycznych, opatrując je taką oto refleksją na temat własnych przeżyć:

Żyję, jak gdybym miał jutro umrzeć; myślę, jak gdyby mi jeszcze wiek cały żyć należało ${ }^{103}$.

II. Ten kilkufazowy dramatyzm przeżywania nieszczęść narodowych z dzisiejszego punktu widzenia był typową reakcją żałobną. W naszym przypadku jej podłoże wyznaczała stopniowa redukcja siły wiążącej z ojczyzną jako obiektem uczuć i czerpania wartości. Było to swoiste „przepracowywanie straty”, w którym po etapie odłączenia, poczucia pustki i braku, pojawił się etap przystosowywania się do nowego środowiska i tworzenia w nim nowych relacji ${ }^{104}$. Nowe formy starań i nadziei ujawniać się zaczęły w wyniku oddzielania „pamięci” o utraconym obywatelstwie. Jako rezultat odsuwania dręczącego uczucia, towarzyszącego uświadomieniu sobie tego faktu, wystąpiło zjawisko stopniowego rozluźnienia emocjonalno-intelektualnych więzi z niedawną przeszłością i w konsekwencji akceptacja straty. Zdarzały się, rzecz jasna, przypadki, że odczuwana żałoba po stracie państwa była szczególnie intensywna, trwała w ostrej postaci, i przedłużając się w czasie, kończyła śmiercią, depresją czy zaburzeniami psychicznymi.

$\mathrm{Z}$ innych charakterystycznych reakcji występujących w tym procesie wymienić można literackie formy jego konkretyzacji do postaci pewnych powtarzających się motywów. Należały do nich: idealizacja ojczyzny i tłumienie wobec niej wszelkich uczuć negatywnych

${ }^{103}$ Cyt. za: M. Brandys, op. cit., s. 49.

${ }^{104}$ Zob. opinię Aleksandra Brücknera:

Po rozgorączkowanym życiu lat 1788 do 1794 nastąpiła cmentarna cisza; unieruchomiony naród leżał, niby niepomny dziejów i znaczenia; cały teraz, zdawało się, żył wedle owej zasady: niech drudzy za łby chodzą, ja się dziwuję (...) Jednostki używały; Berlin dostarczał kredytu lekkomyślnym, ile tylko żądali; bawiono się w Warszawie i we Lwowie do upadłego. Wyrok politycznej i narodowej śmierci sam naród niejako zatwier$\mathrm{dza}$. W istocie nie było śmierci, ani nawet letargu, tylko chwilowe odrętwienie — narkoza, w której organizm przeboleje amputację i włoży się w nowe warunki.

(A. Brückner, Dzieje literatury polskiej w zarysie, t. 2, Warszawa 1921, s. 1). 
(ukazywanie Polski jako odwiecznego dębu, strażnicy Europy, ostoi wolności obywatelskich i wartości chrześcijańskich), pragnienie śmierci i werbalizowanie „zazdrości” pod adresem tych, którzy zginęli w jej obronie, traktowanie poezji elegijnej i funeralnej jako swoistego składnika uroczystości pogrzebowych rozładowujących przeżycia wywołane doznaną stratę, podkreślanie w metatekstowych dywagacjach funkcji terapeutycznej tego typu literatury (wyładowania emocji, uzyskania równowagi, podtrzymania na duchu), zaakceptowanie upadku Rzeczypospolitej poprzez włączenie go w interpretacje religijne i historiozoficzne: równań kulturowych i analogii historycznych, posłannictwa narodowego, predestynacji i misji dziejowej, o wydźwięku zarówno pesymistycznym — dzieje narodów jak losy ludzi są igrzyskiem losu, jak i optymistycznym - historia jest we władaniu Boga i zmierza do pomyślnego rozstrzygnięcia.

Przeżałowanie straty dokonywało się w sposób intelektualny, poprzez wyjaśnienie, wytłumaczenie, próby ogarniącia utraty wolności spekulatywno-filozoficznymi koncepcjami, pozwalającymi zatrzeć poczucie występowania w historii przypadkowości i absurdu. W porządku metafizycznym ze stratą godzono się w różnoraki sposób: przywołując rozmaite koncepcje deizmu z uwzględnieniem futurystycznej teleologii tak w planie jednostkowym, jak i zbiorowym. Powoływano się na analogie z narodem żydowskim zwracając uwagę na Opatrznościowy porządek świata, w którym każdy występek i nieposłuszeństwo są represjonowane. Sięgano po przypadek Hioba, widząc w nim duchową prefigurację cierpień Polaków, dających przed innymi świadectwo swej wierności i stałości wobec wyroków i postanowień boskich. Wykorzystywano także starobiblijną idę̧ przymierza ludu wybranego z Bogiem, które wskutek jednostronnej winy może być zerwane, co wcale jednak nie oznacza, że nie można go odnowić.

Jak się okazuje, dla tych, którzy wyrwali się z sideł rozpaczy, łatwiej było znieść cierpienie przy świadomości własnej winy nż cierpieć w ogóle, bez jakiegokolwiek uzasadnienia. Sam fakt uświadamiania sobie takiej winy stanowi znamienne świadectwo, że część społeczeństwa szybko otrząsnęła się z duchowego załamania po utracie ojczyzny, „przepracowała stratę" i opowiedziała się po stronie życia, wyszukując w porządku prowidencjalnym dla siebie i narodu szczególnie zaszczytne miejsce. Ponieważ owo przepracowanie było procesem z fazami kryzysu i prób jego przezwyciężenia, niezupełnie trafne zdają się być absolutyzujące i wzajemnie sprzeczne względem siebie stanowiska, w których wskazywano bądź to wyłącznie na skrajną desperację odwrócenia się narodu od Boga lub też przeciwnie, wypowiadano się o odrodzeniu ducha religijnego w polskim społeczeństwie wskutek utraty przez nie niepodległości. Skłonić się należy raczej ku przypuszczeniu, że obydwa te zjawiska włączone były w jeden proces i wynikały z siebie nawzajem, dlatego w planie psychologii tak zbiorowej, jak i jednostkowej dadzą się ze sobą pogodzić w linearnych, przyczynowo-skutkowych, zależnościach. Rację natomiast przyznać należy Maurycemu Mochnackiemu, który charakteryzując cechy narodowe Polaków, pisał, że ujawniają się one szczególnie w trudnych i skomplikowanych wydarzeniach historycznych: 
To, co się działo w Polszcze od chwili, jak ziemię naszą źli sąsiedzi rozerwali pomiędzy siebie, pokazuje dostatecznie, że w nas jest pewna siła, którą trzeba nazwać siłą dźwigania się z każdego upadku. U nas tylko wykształciło się i upowszechniło nie znane innym ludom życie po śmierci politycznej ${ }^{105}$.

Trzeba jednak nadmienić, że podobne tym przewartościowania nie dokonywały się od razu. Potrzeba było czasu, aby taka spekulatywna konsolacja znalazła szerszy oddźwięk i aby stała się ideą zapładniającą inne obszary wartości narodowych.

Dodajmy te $\dot{z}, \dot{z}$ e „przepracowanie straty” dokonywało się nie tylko w planie religijnym. Literatura porozbiorowa po 1797 roku w swej zdecydowanej większości nastawiona była na poszukiwanie takich koncepcji życia, które utrwalałyby ideał polskości i pozwalały przetrwać rozbitemu granicami państw zaborczych narodowi. Ignacy Krasicki źródeł ocalenia szukał w wartościach klasycznych, Stanisław Trembecki w kulturze i Lukrecjuszowskim materializmie, Koźmian, Feliński, Godebski, Sygiert, Bończa Tomaszewski w powrocie do antycznych i staropolskich ideałów ziemiańskich, członkowie TPN w nauce oraz kultywowaniu narodowej historii i języka.

Także w proces przeżałowania straty należy włączyć pierwsze mity narodowe tworzone na bazie niedawnej przeszłości i rozprzestrzeniający się wówczas kult narodowych bohaterów, z Kościuszką na czele, o którym tuż po jego uwięzieniu opowiadano, że uszedł w przebraniu z rąk Moskali. Naczelnik miał posiadać jakoby czarnoksięskie zdolności, gdyż widywano go w wielu miejscach nieistniejącej Rzeczypospolitej. Miał też w Paryżu, Wiedniu i Stambule, czynić zabiegi dla przygotowania kolejnego narodowego zrywu. Zaniepokojeni tym zjawiskiem oficerowie rosyjscy ekskortujący rannego Kościuszkę do Petersburga wystawiali go na widok publiczny, aby rozwiać te pogłoski ${ }^{106}$.

O sposobie rozchodzenia się podobnych wieści możemy dowiedzieć się z „Gazety Warszawskiej”, która 28 kwietnia 1795 roku informowała o nowym Kościuszce, podburzającym w Krakowskiem chłopów do buntu:

Zdrajca ten zowie się Jakub Romheld, rodem z Kaniowa na Ukrainie (...) Dnia 4 t. m. przyszedł do wsi Czytcze, gdzie Żyd Henoch Salomonowicz jest gościnnym. Tam zastał 5 chłopów, z którymi gdy się gorzałki napił, zwierzył im się, iż jest Kościuszkiem, któremu się udało uciec z Rosji. Modlił się potem

\footnotetext{
${ }^{105}$ M. Mochnacki, Poustanie narodu polskiego w roku 1830 i 1831, t. 1, Berlin-Poznań 1863, s. 1-2.

106 Zob. A. Kijowski, O dobrym Naczelniku i nieztomnym Rycerzu, Kraków 1984, s. 23-24. Wydarzenia te wspomina J. U. Niemcewicz:

Na Wołyniu odebrał Chruszczew doniesienie od Fersena, iż Polacy rozgłosili po kraju, iż prawdziwy Kościuszko uszedł cały z bitwy i że na miescu jego Moskale fałszywego wiozą; by nieprawdę wieści tej dowieść nakazno Chruszczewowi, aby po wszystkich stanowiskach zwoływał obywateli i pokazywał im Kościuszkę. Chwile te równie okrutnymi były dla patrzących jak i dla pokazywanych; w zranionym wodzu widzieli oni już zamordowaną ojczyznę swoją. Ileż łez wzajemnych! Dotąd ludzie pokazywali drapieżne zwierzęta, dziś było przeciwnie.
}

(J. U. Niemcewicz, Pamiętniki czasów moich, opr. J. Dihm, t. 2, Warszawa 1957, s. 122). 
i śpiewał wraz z nimi, a na ostatek zaczął im tyle rzeczy niezrozumiałych przepowiadać, iż na kolana przed nim padłszy, cześć mu boską dawali. W ciągu tej uroczystości oświadczył nasz pseudo-Kościuszko, iż od Boga jest zesłanym sądzić żywych i umarłych i że temu powołaniu zadość czynić rozpocznie od wygładzania zupełnego Żydów ${ }^{107}$.

Na początku 1795 roku Rumiancew komunikował Repninowi, że na bramie klasztoru bazyliańskiego w Krzemieńcu ukazał się zatrważający napis:

Kto kocha wolność, Kościuszkę i Ojczyznę

Niech macha co prędzej na Wołoszczyznę.

Tad. Kos. ${ }^{108}$ 